Discussion Paper No. 16-008

Book-Tax Conformity and Reporting Behavior A Quasi-experiment

Maria Theresia Evers, Ina Meier, and Katharina Nicolay

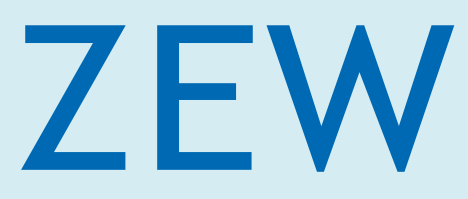

Zentrum für Europäische Wirtschaftsforschung $\mathrm{GmbH}$ Centre for European Economic Research 
Discussion Paper No. 16-008

\title{
Book-Tax Conformity and Reporting Behavior - A Quasi-experiment
}

\author{
Maria Theresia Evers, Ina Meier, \\ and Katharina Nicolay
}

Download this ZEW Discussion Paper from our ftp server:

http://ftp.zew.de/pub/zew-docs/dp/dp16008.pdf

Die Discussion Papers dienen einer möglichst schnellen Verbreitung von neueren Forschungsarbeiten des ZEW. Die Beiträge liegen in alleiniger Verantwortung der Autoren und stellen nicht notwendigerweise die Meinung des ZEW dar.

Discussion Papers are intended to make results of ZEW research promptly available to other economists in order to encourage discussion and suggestions for revisions. The authors are solely responsible for the contents which do not necessarily represent the opinion of the ZEW. 


\title{
Book-Tax Conformity and Reporting Behavior-A Quasi-experiment
}

\author{
Maria Theresia Evers*, Ina Meier**, Katharina Nicolay***
}

January 2016

\begin{abstract}
We examine how a comprehensive change in book-tax conformity affects firms' reporting behavior. To this end, we exploit a Reform Act as a quasi-natural experiment which implied a decrease in book-tax conformity in Germany in 2010. In particular, this reform allows firms to exercise tax accounting options independently from financial accounting. Our study builds on a unique dataset of linked individual financial statements and actual tax return data. It covers roughly 150 incorporated firms for the years 2008 to 2012. Exploiting the exceptional change in conformity, we contribute to the ongoing debate on the impact of booktax conformity. Our results show that profitable companies, which have a clear tax sheltering incentive, actually use the newly introduced reporting leeway to manage taxable income downwards. This is especially attributable to companies exploiting favorable tax depreciation rules. Moreover, we find larger opportunistic tax reporting responses for small companies with less complex and predominantly domestic group structures. In addition, we observe that a decrease in book-tax conformity induces a decrease in the general persistence of taxable income, but at the same time gives rise to higher financial earnings persistence. This corroborates our finding of increased tax sheltering activity in post reform years.
\end{abstract}

JEL Classification: H20, H25, K34, M41

Keywords: book-tax conformity; book-tax differences; tax sheltering; earnings persistence

$\begin{array}{ll}* & \text { ZEW Mannheim } \\ * * & \text { University of Mannheim } \\ * * * & \text { ZEW Mannheim and University of Mannheim }\end{array}$

We gratefully acknowledge the considerable support of Martina Ortmann-Babel and Ute Benzel (both Ernst \& Young GmbH, Germany). We are indebted to Ernst \& Young GmbH, Germany for facilitating this research and providing access to anonymous corporate tax return data. Moreover, we owe thanks to the MannheimTaxation Science Campus (MaTax) for funding this research. We also thank Martin Jacob, Johannes Voget, Christoph Spengel and participants of the $5^{\text {th }}$ Workshop on Current Research in Taxation in Prague and the MaTax Campus Meetings in Mannheim for helpful comments. Finally, we would like to thank the Stiegler Stiftung for financing conference participations. Any remaining errors are, of course, our own. 


\section{Introduction}

There is an ongoing discussion among policymakers and academics on the costs and benefits of book-tax conformity. Particularly in the US, the question as to whether the link between financial and tax accounting should be tightened, has been debated intensely in the past decade (Desai (2003, 2005); Hanlon and Heitzman (2010)). Essentially, proponents of an increase in book-tax conformity (e.g. Desai (2005)) argue that a one-book system would offer less leeway for opportunistic reporting behavior, i.e. earnings management and/or tax sheltering, and thus increase the quality of disclosed earnings. Opponents of conformity (e.g. Hanlon et al. (2008)), by contrast, whilst invoking the divergent objectives and recipients of both financial and tax reporting, argue that an alignment of the two sets of accounts would result in the loss of valuable information and therefore give rise to a decline in earnings quality.

The existing empirical evidence on the effects of book-tax conformity with regard to the extent of opportunistic reporting behavior and to earnings quality is not entirely unambiguous. There is, for example, no unanimity as to whether book-tax conformity leads to more or to less earnings management and tax sheltering (Blaylock et al. (2015); Tang (2014)). Furthermore, most studies find that the persistence of earnings is better in contexts of low conformity. However, at the same time, there is also evidence that large book-tax differences, which by intuition are rather to be expected in systems of low book-tax conformity, are indicative of earnings that are less persistent (Hanlon (2005)).

With respect to the measurement of book-tax differences/book-tax conformity and the empirical assessment of their influence, the majority of studies have in common that they (i) use a proxy for taxable income and (ii) derive the impact from cross-country variation, crossfirm variation or within-firm variation over time without an exogenous change of book-tax conformity legislation to identify its impact. In our study, we use a setting in which firms have been subject to a comprehensive change in conformity as a consequence of the Accounting Law Modernization Act (Bilanzrechtsmodernisierungsgesetz (BilMoG)) in Germany. In addition, we employ a dataset of linked individual financial statements and actual tax return data, thus avoiding problems of approximating taxable income (Hanlon (2003)).

The BilMoG reform entered into force in 2010 and constituted a considerable change with regard to the traditionally close relationship between financial and tax accounting in Germany. A major change brought about by this reform is that it enables firms to exercise tax accounting options independently from financial accounting. This allows companies to decrease their taxable income without simultaneously decreasing their financial income and therefore creates incentives for tax sheltering.

Papers on a change in conformity are rare. Examples for partial modifications in the US setting include Dhaliwal and Wang (1992), Guenther et al. (1997) and Hanlon et al. (2008). More recently, Chan et al. (2010) and Chan et al. (2013) address a comprehensive change in conformity in China. We are, however, to the best of our knowledge, the first to exploit the transition from a one-book towards a more two-book oriented system in a European country 
with a long-standing accounting tradition. In addition, and in contrast to most other studies using proxies for tax variables, we are able to observe the true taxable income in our data.

We contribute to the existing literature on the impact of a change in book-tax conformity on reporting behavior. Firstly, we assess whether new reporting discretion resulting from the decrease in book-tax conformity is actually exploited despite additional requirements to document deviations between financial and tax accounting. Using individual financial and tax accounts allows us to attribute a change in book-tax differences to tax sheltering rather than to financial earnings management. Secondly, we examine how the change in book-tax conformity affects the persistence of taxable and financial income. We do so to gain further evidence that the newly introduced scope for opportunistic reporting behavior induces tax sheltering rather than earnings management. Moreover, we are thereby able to illustrate the interaction between book-tax conformity, book-tax differences and earnings quality.

Our analysis proceeds in the following way. First, we illustrate the development of book-tax income differences graphically to get prior insights into whether a potential reform impact is visible in the data. In particular, we observe that the total book-tax income difference becomes positive (i.e. financial income exceeds taxable income) in the fiscal year 2010 which indicates opportunistic tax reporting behavior. The same applies to income differences relating to Property, Plant and Equipment (PPE). We interpret this as an indication that companies make beneficial use of deprecation options in order to decrease taxable income.

In the empirical analysis, we directly exploit the 2010 reform in a difference-in-difference regression approach. Our results suggest that companies do indeed use the newly introduced discretionary reporting scope. More precisely, we find that profitable companies which face a clear tax sheltering incentive exhibit comparably higher book-tax differences subsequent to the decrease in conformity. We particularly trace this effect back to book-tax differences relating to PPE and thus to companies making use of favorable tax depreciation rules. Furthermore, we find that small firms featuring less complex and predominantly national group structures are more likely to engage in opportunistic tax reporting behavior.

With respect to the persistence of taxable and financial income, our results suggest that a decrease in book-tax conformity leads to a decline in the persistence of taxable income which we attribute to the distortive impact of the newly arisen tax sheltering options. In contrast to that, we observe an increase in the persistence of financial accounting earnings. This rules out a possible influence of earnings management on our findings. Moreover, it demonstrates that both reporting lines contain distinct information, parts of which are lost in case of an alignment (Hanlon et al. (2005)).

In terms of policy contribution, our results inform the debate on the effects of book-tax conformity with valuable findings from a quasi-experimental setting. In particular, we show that a switch from high to low conformity creates discretion for opportunistic reporting which is exploited for tax sheltering despite higher documentation costs. This finding speaks against a shift towards a two-book system. At the same time, we show that detaching financial and taxable income increases the persistence of financial income, thus suggesting an increased information content of financial earnings in a two-book system. This is reasonable, since 
financial reporting numbers are no longer influenced by tax reporting objectives and there are no incentives for earnings management in individual financial statements. Essentially, the reduced persistence of post-reform taxable income, however, indicates that earnings quality deteriorates in a two-book system if incentives for opportunistic behavior are present. Hence, we conclude that a switch from high to low conformity increases opportunistic reporting behavior while not improving the information content with regard to those reported income numbers for which incentives for opportunistic behavior are present.

The paper continues as follows: Section 2 discusses the related studies on the effects of booktax conformity and outlines how our study contributes to this strand of literature. Section 3 provides an overview of the German institutional setting and of the change in book-tax conformity induced by the BilMoG-Reform Act. We describe our dataset in Section 4. Section 5 presents the descriptive and graphical analysis of book-tax income differences. Section 6 describes the empirical approach including hypothesis development and discusses the results. Subsection 6.1 refers to the analysis of a change in book-tax conformity on the book-tax income gap and tax sheltering whereas in Subsection 6.2 we investigate the relationship between book-tax conformity and the persistence of taxable and financial income. Finally, section 7 concludes.

\section{Related literature}

\subsection{General book-tax conformity discussion}

In the last decade, the divergence of book and tax income in the US (Desai (2003), (2005); Mills et al. (2002); Plesko (2002); Manzon and Plesko (2002); Hanlon and Shevlin (2005)) and corporate reporting scandals such as the one concerning Enron, have led to an intense and ongoing debate as to whether or not financial accounting income and taxable income should be more strongly aligned. At the same time, however, several countries, including Germany, which have traditionally had a much higher degree of book-tax conformity than the US (Harris et al. (1994)), have recently moved towards a separation of financial and tax reporting. In Germany, this movement is aimed at achieving greater convergence with the IFRS and at enhancing financial statement comparability (Deutscher Bundestag (2008)). Moreover, given the traditionally close link between financial and tax reporting in Germany, it seems reasonable to assume that delinking the two reporting lines is further motivated by the German legislator's aim to avoid the influence of an external standard setting board on tax law.

Proponents $^{1}$ (Desai (2003), (2005); Whitaker (2005); Shaviro (2009)) of increased book-tax conformity in particular point to managers' reduced scope for aggressively reporting on both financial profits and taxable income. On the one hand, inflating earnings would entail an increase in tax payments; on the other hand, understating taxable income would imply reporting lower profits to shareholders and other capital market participants. Hence, book-tax conformity would constitute an incentive not to report opportunistically in either direction, but instead encourage firms to disclose an unbiased earnings number more closely approximating

For extensive discussions on the pros and cons of increased book-tax conformity, see Hanlon and Shevlin (2005); McClelland and Mills (2007); Hanlon and Maydew (2009). 
their "true economic income". Thus, the quality of reported earnings would be enhanced and the firms' overall economic performance would become more transparent. Furthermore, the provision of one single set of rules could potentially lead to a reduction in compliance and administrative costs.

Opponents (Hanlon et al. (2005); Hanlon and Shevlin (2005); Hanlon et al. (2008); McClelland and Mills (2007)) of an increase in book-tax conformity, however, refer to the divergent objectives of both reporting lines (Hanlon and Heitzman (2010)) and invoke one major disadvantage of conforming book and taxable income: a loss of information contained in earnings in particular for capital markets and therefore a decrease of earnings quality (also see subchapter 2.4). That argument is based on the notion that accounting earnings are intended to inform about firm performance, whereas tax law is driven by governments' budgetary needs and other objectives. Moreover, Hanlon and Shevlin (2005) question the claim that conformity will actually reduce tax sheltering, reasoning that book income would most likely be conformed to tax income, thus creating strong incentives for tax competition. ${ }^{2}$

Empirically, due to the lack of fundamental reforms of book-tax conformity, there is little direct evidence of the impact of changes in conformity on reporting behavior. As Hanlon and Heitzman (2010) point out, in "examining what would happen here in the U.S. if book-tax conformity were adopted, the ideal research design cannot be employed since the U.S. has not switched from a full book-tax conformity system to a non-conformed system (or vice versa)". They, therefore, underline the potential of using systematic changes in book-tax conformity for further investigating reporting behavior before and after a change. The few existing papers based on US data address contexts in which book-tax conformity changed partially.

One example is Dhaliwal and Wang (1992) who examine whether the book income adjustment, which became part of the annual minimum tax (AMT) system in 1987, alters financial reporting behavior. They find that the book income adjustment, according to which half of the difference between book and taxable income has to be included in the AMT tax base, prompts firms that are likely to be affected by the adjustment to shift income across years in order to reduce the AMT burden. In addition, Guenther et al. (1997) examine the financial reporting behavior of large, publicly traded firms that, following the enactment of the 1986 Tax Reform Act in the US, became subject to an increase in book-tax conformity due to a switch from the cash method to the accrual accounting method for tax purposes. They conclude that a stronger alignment of financial and tax reporting induced affected firms to defer financial accounting income. ${ }^{3}$

In contrast to this setting of increasing conformity, Chan et al. (2010) examine the case of a decrease in book-tax conformity in China. More specifically, Chan et al. (2010) assess

2 Hanlon and Shevlin's argument goes as follows: If book and tax income were to be conformed, it would be more likely that financial accounting income is conformed to taxable income, as Congress would probably not be willing to leave tax revenue determination to the Financial Accounting Standards Boards. If that holds true, market participants would know that the reported earnings are those on which tax is computed and would no longer rely on it as strongly as a source of information about firm performance. Hence, if it was clear that capital market participants do not any longer interpret earnings as performance measure anyway, firms would face an incentive to understate earnings in order to keep taxes low.

3 Hanlon et al. (2008) build on this natural experiment as well. For more details, see 2.4. 
whether a change of the financial reporting system from tax-based financial accounting towards the IFRS affects the informativeness of book-tax differences for tax non-compliance, i.e. the violation of tax rules. Indeed, they find that a decrease in conformity increases fraudulent tax reporting. In a further study exploiting the decrease in conformity in China, Chan et al. (2013) conclude that when book-tax conformity is reduced, larger firms pay proportionately less tax than smaller firms, i.e. they have greater ability to exploit the scope in independent tax reporting and thus save on tax payments.

Apart from the paucity of exploitable institutional changes, only few papers are based on actual tax return data which is usually not available to the public. Examples of such studies building on tax return data include Lisowsky (2009), Mills (1996), Mills and Newberry (2001), Mills et al. (2002), Plesko (2007) and Chan (2010). However, the majority of empirical investigations rely on proxies for tax positions estimated from financial statements. For instance, in order to estimate taxable income, the current tax expense on the income statement is commonly grossed-up by the statutory tax rate. As Hanlon (2003) points out, this approach may, however, be subject to several estimation problems, as current tax expense and actual tax liability on the tax return usually do not correspond. Hanlon argues that additional disclosures would be necessary to more accurately determine taxable income from financial statements.

\subsection{Book-tax conformity, book-tax differences, tax sheltering and earnings management}

Book-tax differences relate to deterministic, legal differences between accounting standards and tax law and/or to discretionary differences attributable to incentives inherent in financial and tax reporting (Mills et al. (2002)). Various studies assess how (estimated) book-tax differences relate to aggressive tax reporting (e.g. Mills (1996), (1998); Manzon and Plesko (2002); Desai (2003); Desai and Dharmapala (2006)), whereas other papers (e.g. Philips et al. (2003); Lev and Nissim (2004); Hanlon et al. (2009)) attribute large book-tax differences to earnings management. ${ }^{4}$ Still other studies aim to consider both, earnings management and tax sheltering (Ayers et al. (2010); Blaylock et al. (2012), Seidman (2010)). In that regard, Badertscher et al. (2009) and Frank et al. (2009) find that some firms indeed report high book income to investors and low taxable income to tax authorities if both lines of reporting are not conformed. The question as to whether book-tax conformity leads to more or to less opportunistic reporting behavior remains, however, somewhat unclarified: Watrin et al. (2014) construct an index to capture international differences in book-tax conformity and conclude that firms operating in one-book systems (less scope for discretionary book-tax differences) conduct significantly more (upward) earnings management in their consolidated financial statements than firms which operate in an environment of low book-tax conformity. In line with these findings, Blaylock et al. (2015) conclude that book-tax conformity is associated with significantly more, not less, earnings management. By contrast, recent evidence by Tang (2014) suggests that high book-tax conformity deters overall earnings management and tax avoidance. This fits in with Coppens and Peek (2005) who establish that private firms in high conformity countries are less likely to engage in earnings management. Likewise, Salbador and Vendrzyk (2012) identify periods with differing levels of conformity

4 See Dechow et al. (2010) for a broad review of the earnings management literature. 
across the years 1956 to 2010 and demonstrate that earnings management is more prevalent in low conformity periods.

\subsection{Book-tax differences and particular company features}

Additional studies investigate the extent to which book-tax differences and/or opportunistic reporting activities can be explained on the basis of particular company characteristics. Mills and Newberry (2001) find that public firms tend to exhibit larger book-tax differences than private firms and that these differences tend to be more positive for firms with larger profitability and more negative for unprofitable firms. Similarly, Mills et al. (2002) conclude that profitable firms and firms with multinational operations have larger book-tax income differences. They also find that the most significant increase in the gap between book and taxable income has occurred in the financial industry. This is in line with Plesko's (2002) finding that book-tax differences are greater in the financial and information industries. In addition, Manzon and Plesko (2002) demonstrate that book-tax differences can be determined by the change in firm sales and the level of PPE.

Finally, on the basis of confidential tax return data sourced from the Internal Revenue Service, Lisowsky (2010) develops a model to infer the likelihood that a firm engages in tax sheltering. Amongst other things, his results indicate that this likelihood positively correlates with firm profitability and size, but shows negative correlation with leverage.

\subsection{Book-tax conformity, book-tax differences and earnings quality}

Related to the issue of opportunistic reporting, a further strand of literature examines the association between book-tax conformity, book-tax differences and particular properties of (financial accounting) earnings quality, such as the persistence or value relevance of earnings. Studying earnings persistence as a feature of earnings quality builds on the notion that - if not reported opportunistically and thus truthfully reflecting the companies' economic condition earnings should have explanatory power with regard to future profits. Similarly, value relevance refers to the ability of disclosed earnings to capture firm value as reflected in stock market returns.

Joos et al. (2000) find that stock returns are less correlated with earnings when book-tax differences are large and thus conclude that large book-tax differences negatively impact on earnings quality. Similarly, Lev and Nissim (2004) establish that large book-tax differences are correlated with lower earnings quality. Hanlon (2005) as well posits that large book-tax differences, as opposed to small book-tax differences, are indicative of less persistent earnings. More specifically, Blaylock et al. (2012) show that firms with large positive booktax differences, which can be attributed to upward earnings management, have lower earnings persistence than other firms with large positive book-tax differences.

In addition, Hanlon et al. (2005) examine the relative and incremental information content of book and (estimated) taxable income. Studying the association between the two earnings figures and stock returns, they find that book income has higher explanatory power, but that both income measures exhibit incremental explanatory power. They therefore conclude that information content would be lost if the two income measures were conformed, thus 
decreasing the quality of earnings. In line with that, Hanlon et al. (2008), building on the natural experiment first exploited by Guenther et al. (1997) (see Section 2.1.), find that an increase in conformity causes earnings to be less informative compared to earnings of firms that were not subject to the change in conformity. The authors argue that increased conformity deters earnings quality because rather than reflecting economically valuable information, earnings are reported such that taxes are minimized. This is in contrast to Desai's (2005) suggestion that increased conformity can improve earnings quality by limiting earnings management.

Finally, several cross-country studies examine the relation between country-specific factors, including book-tax conformity and earnings quality measures. Ali and Hwang (2000) as well as Guenther and Young (2000) conclude that financial accounting earnings feature lower value relevance in countries with high conformity. Likewise, Atwood et al. (2010) study the relationship between book-tax conformity and earnings persistence based on an index capturing the degree of book-tax conformity in various countries. Their evidence also suggests that earnings are less persistent in countries with high book-tax conformity. However, unlike these papers, Hung (2001) and Leuz et al. (2003) do not find any effect of book-tax conformity with regards to differences in the properties of earnings in their crosscountry studies. Moreover, intuitively the observation that larger book-tax differences negatively impact on earnings quality seems to be at odds with the predominant finding that the same negative effect applies to high book-tax conformity, since large book-tax differences would rather be expected in contexts of low conformity. In particular, this is somewhat confusing with regard to evidence building on indices for book-tax conformity such as the one by Atwood et al. (2010) ${ }^{5}$, Watrin et al. (2014) and Tang (2014) which are based (directly or indirectly) on book-tax differences.

To sum up, existing empirical studies entail two major shortcomings: First, most papers - in absence of tax return data - use proxies for tax positions from financial statements which may be subject to several estimation problems. Second, only few studies observe an institutional change and can therefore demonstrate possible behavioral responses to changes in conformity. Essentially, we are able to overcome these concerns in our study. With regard to the research questions addressed, we shed new light on the impact of a change in book-tax conformity on reporting behavior in terms of tax sheltering. Moreover, we illustrate the interaction between book-tax conformity, book-tax differences and earnings quality.

\section{Institutional background}

\section{Changes in the level of book-tax conformity in Germany}

The Accounting Law Modernization Act (Bilanzrechtsmodernisierungsgesetz (BilMoG)), which entered into force in 2010 weakened the strong linkage between financial and tax

\footnotetext{
Atwood et al. (2010) argue that book-tax differences are greater for firms that operate in countries with lower book-tax conformity. They suggest that those larger book-tax differences result in more unexplained crosssectional variation in current tax expense. Therefore, they infer the degree of required conformity in a particular country from the amount of observed variation in current tax expense that cannot be explained by the variation in pre-tax earnings.
} 
accounts in Germany. It can thus be considered to have induced a transition from a rather strict one-book system to a more two-book oriented system.

Germany has traditionally been a high book-tax conformity country with one of the closest relationships between financial and tax accounting worldwide (Schön (2005); Lamb et al. (1998)). In that regard, the authoritative principle (Maßgeblichkeitsprinzip Sec. 5 (1) S. 1 $\mathrm{EStG}$ ) has been one of the major reasons for the strong linkage between the determination of financial and taxable income. This principle implies that the recognition and measurement policies applied in individual financial accounting basically have to be incorporated into tax accounting. The reverse authoritative principle (umgekehrte Maßgeblichkeit (Sec. 5 (1) S. 2 EStG old version)) additionally stipulated that tax accounting options had to be exercised in accordance with financial accounting, i.e. if a firm made use of tax accounting advantages, the same values had to be recognized in financial accounts. If specific compulsory tax regulations superseded financial accounting, e.g. due to the different objectives of financial and tax accounts, it was, however, possible for deviations between financial and tax accounts to occur. Table 1 in the Appendix provides an overview of the authoritative principle and such possible deviations in the Pre-BilMoG era.

Since the enactment of the reform, which abolished the reverse authoritative principle, it has been possible to exercise tax accounting options independently from the accounting treatment in individual financial statements. The changes in the authoritative principle induced by the BilMoG-Act are also listed in Table 1 (column "Post-BilMoG", marked in green).

The possibility of exercising tax accounting options independently comes, however, along with additional documentation requirements; namely the obligation to keep ongoing registers (Sec. 5 (1) S. 2 EStG) detailing the deviations between financial and tax accounts.

Overall, the adjustment of the authoritative principle by the BilMoG-Act has led to greater leeway for companies' decision-making when it comes to using tax accounting options advantageously without recognizing the same values in financial accounts. It is expected that this greater flexibility will lead to increased book-tax differences in Germany.

\section{Book-tax differences before and after the BilMoG-Act}

Balance sheet adjustments can generally be divided into deterministic and discretionary booktax differences. While the former arise from different mandatory regulations under tax and financial accounts, the latter are not compulsory but may result from an independent use of tax and/or financial accounting options. Such differences may therefore reflect opportunistic reporting behavior, namely earnings management or tax sheltering. Table 2 in the Appendix provides an overview of accounting items with book-tax differences before and after implementation of the BilMoG-Act under German law. Prior to the implementation of the BilMoG-Act, the majority of book-tax differences were deterministic or discretionary due to financial accounting options. Subsequent to the introduction of the BilMoG-Act, however, tax accounting options can now be exercised independently and therefore opportunistically, thus creating more leeway for discretionary book-tax differences in terms of tax sheltering. New potential powers of discretion (see Table 2, marked in green) have emerged especially with 
respect to low-value assets, the valuation of inventories, the special item with reserve component $^{6}$ and most importantly depreciation rules (regular and exceptional). As tax accounting options can be used independently regarding these reporting items, taxable income can be managed downwards without simultaneously decreasing financial income (Frank et al. (2009)). If managers make use of this new tax planning scope, it is expected that book-tax income differences will increase after the BilMoG-Act. Since the balance sheet adjustments described above are predominantly temporary in that they result from differences in the timing of income and expenses recognized under both accounting systems and should reverse at some point, the tax sheltering impact should be most prevalent directly after the introduction of the BilMoG-Act (2010) and diminish over time. ${ }^{7}$

In addition to these balance sheet adjustments, German tax law also enforces a number of permanent, mandatory off-balance sheet adjustments. These differences arise when a particular income or expense is accrued under tax accounting, but will never be recognized under financial accounting or vice versa. Examples are tax exempt dividend income according to Sec. 8 b Corporate Income Tax Act (KStG), non-deductible expenses (Sec. $10 \mathrm{KStG}$ ) or investment allowances. The BilMoG-Act did not, however, change any regulations relevant to off-balance sheet adjustments, and these are not, therefore, a focus of our analysis.

\section{Data and sample characteristics}

We use a unique, anonymized linked sample of financial statements and tax return data for the years 2008 to 2012. Data was provided by Ernst \& Young GmbH, Germany (EY). This is exceptional to the extent that tax return data is, in general, not publicly available in Germany. Although the Corporate income tax statistics contains micro level tax return data, this information is not published on a yearly basis as a panel and it is not possible to merge this tax data with financial statements or other firm characteristics. Our dataset, by contrast, comprises individual financial statements prepared under German Generally Accepted Accounting Principles (balance sheet, profit and loss statement) as well as tax balance sheets, tax reconciliations and tax declarations from tax returns. In addition, we requested that EY collect information regarding various firm characteristics, e.g. the firms' industry affiliation or previous reorganizations. As the sample entails the years 2008 to 2012, our panel covers both pre- and post-reform years.

Using tax return data linked with financial data enables us to compute actual book-tax balance sheet and book-tax income differences, rather than estimating these items on the basis of publicly available financial accounts. We can, therefore, overcome the discussed estimation problems and measurement errors and as such increase the power of statistical tests.

Unlike the majority of other studies, in particular those based on US data, which examine consolidated financial statements, we use single financial statements. We consider this

6 German tax law grants, for example, a rollover relief for buildings (Sec. $6 \mathrm{~b} \mathrm{EStG)}$ or a replacement reserve under certain conditions (Sec. 6.6 EStR).

7 In the US setting, there are more specific, permanent tax sheltering instruments (e.g. the valuation allowance, the tax contingency reserve, and the amount of foreign earnings designated as permanently reinvested) which have, however, no equivalent in Germany. For more details see Hanlon/Heitzman (2010); Graham et al. (2012). 
approach appropriate for several reasons: First, taxable income is derived from individual accounts and the tax figure reported in consolidated accounts is aggregated from individual statements. It is thus straightforward to determine opportunistic tax reporting in individual accounts (Watrin et al. (2014)). Second, we can thus more clearly attribute changes in reporting behavior to tax sheltering, since earnings management that plays a role for listed firms and is more relevant for consolidated accounts should be less present in individual accounts due to lower capital market pressure. Third, the information content of financial income reported in individual accounts is still meaningful, since individual financial statements are relevant for determining the amount distributable as dividends to investors.

In short, we asked EY to select incorporated firms covering six different industries, three different size classes (the definition of size classes follows Sec. 267 of the German Commercial Code) and different postal code areas. Due to divergent reporting requirements, we excluded banks, insurances and other financial institutions. Table 3 provides an overview of the distribution of the sample with regard to these parameters. The comparison with the entire population of German corporations in the German Corporate Income Tax statistics shows that our sample is biased towards large firms and that the Manufacturing sector is overrepresented, whereas our sample comprises fewer firms from the Construction and Services industries. This distortion can also be found in large commercial datasets such as Amadeus provided by Bureau van Dijk and is not unique to our sample of EY clients. It is most likely due to publication requirements. Furthermore, we cross-check our data by reference to the work of Watrin et al. (2014) who use a much broader dataset of European firms from the Amadeus database with a huge subset of German firms. They put forward a mean absolute value of approximated permanent book-tax differences of 0.0924 for Germany. If we replicate the construction of this proxy with our data, we obtain a similar value of 0.0859. This leaves us confident that the results of our study are not more systematically biased than studies based on broader commercial data sets.

Table 3: Sample distribution

\begin{tabular}{|c|c|c|c|c|c|}
\hline \multirow{2}{*}{ Industry } & Sample & Population & \multirow{2}{*}{$\begin{array}{l}\text { Size } \\
\text { (Sec. 267 HGB) }\end{array}$} & Sample & Population \\
\hline & \multicolumn{2}{|c|}{ Frequency } & & \multicolumn{2}{|c|}{ Frequency } \\
\hline Manufacturing & $30.46 \%$ & $10.60 \%$ & Small & $9.46 \%$ & $51.80 \%$ \\
\hline Construction & $1.39 \%$ & $9.40 \%$ & Medium & $44.78 \%$ & $33.39 \%$ \\
\hline Trade & $13.35 \%$ & $16.70 \%$ & Large & $45.76 \%$ & $14.82 \%$ \\
\hline $\begin{array}{l}\text { Service and } \\
\text { others }^{8}\end{array}$ & $54.8 \%$ & $63.30 \%$ & & & \\
\hline Total & $100 \%$ & $100 \%$ & Total & & $100 \%$ \\
\hline
\end{tabular}

Note: This table characterizes the data sample and compares the relative coverage of size classes and industries to the population of German corporations (Corporate income tax statistics, 2010).

The initial sample consists of approximately 150 unique incorporated firms. The number of observations per year varies slightly as we do not have data covering the entire sample period

8 From the six industry categories covered in our sample, this category also comprises firms from the Energy and IT sector. We condense industries this way to attain comparability with the Corporate income tax statistics. 
(five years: 2008-2012) for all firms (unbalanced panel). In total, our sample consists of 725 firm-year observations.

Our dataset enables us to identify deviations between financial and tax reporting at the level of single balance sheet items, both with respect to book-tax balance sheet and book-tax income differences. Book-tax balance sheet differences entail cumulative effects relating to accrual accounting decisions made in previous reporting periods. They do not, however, necessarily provide information on income differences relating to the current period. We therefore do not further analyze these positions. Book-tax income differences, by contrast, capture annual effects and can therefore be considered as a more suitable indicator for opportunistic reporting than balance sheet differences. In particular, they reflect how book income is adjusted in order to determine tax balance sheet income. Given that we are interested in differences between book and taxable income which relate to book-tax balance sheet differences, we do not, however, examine total book-tax income differences including off-balance sheet adjustments. As described in Section 3, off-balance sheet adjustments are, in principle, deterministic and are not related to accrual accounting. We therefore consider these to be irrelevant for our analysis of opportunistic tax reporting. Any following uses of the term "taxable income" actually refer to tax balance sheet income before off-balance sheet adjustments.

\section{Descriptive Evidence: Book-Tax Differences pre- and post-reform}

In Figure 1, we plot the total book-tax income difference scaled by total assets for the years 2008-2012. The solid black line represents the sample mean, the dashed black line depicts the average for profitable firms and the dashed grey line the average for unprofitable firms. The book-tax difference turns positive if taxable income falls below financial income, thus potentially indicating aggressive tax reporting behavior. A negative book-tax difference, in turn, results if taxable income exceeds financial income. 
Figure 1: Total book-tax income difference, scaled by total assets

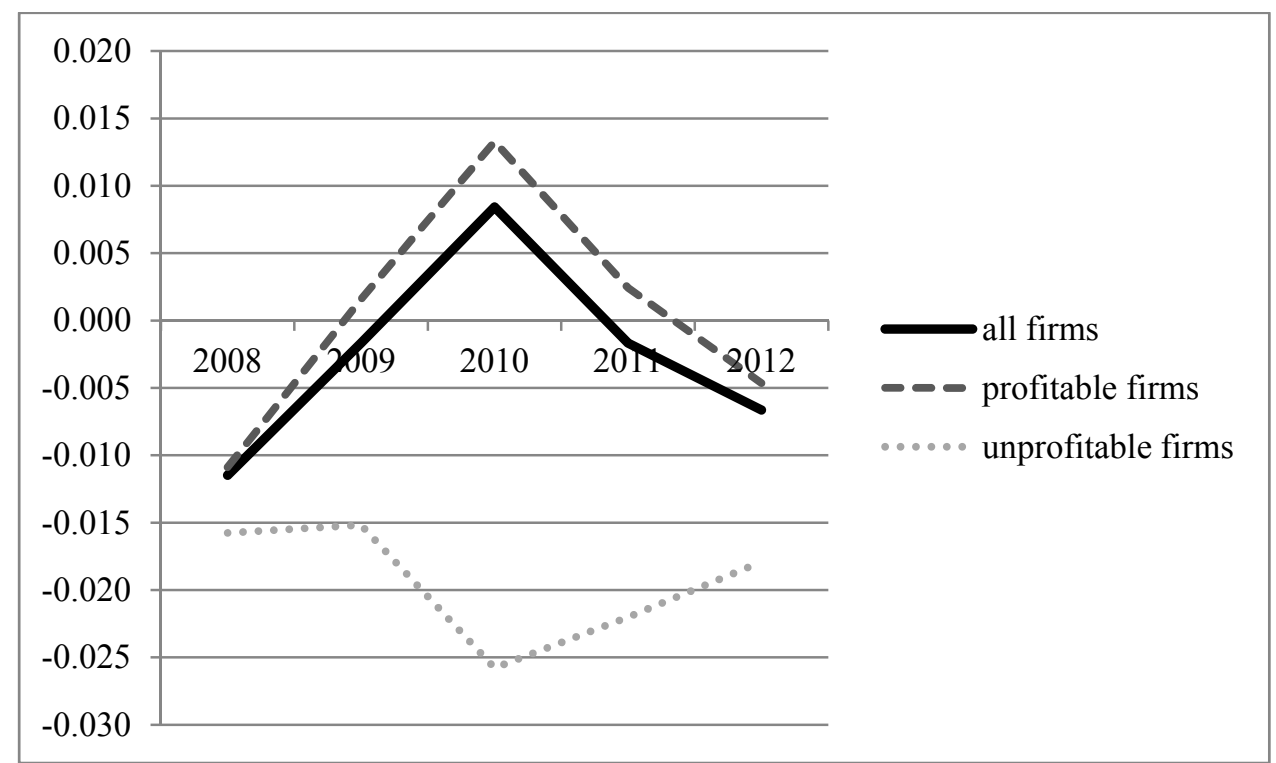

Note: This figure shows the mean total book-tax difference (scaled by total assets) over the sample period. The solid black line represents the sample mean, the dashed black line depicts the average for profitable firms and the dashed grey line the average for unprofitable firms.

In the years 2008 and 2009, we observe negative book-tax differences. Strikingly, the overall book-tax difference becomes positive in the year 2010 when the implemented Reform Act introduced new reporting discretion. This suggests that the tax sheltering scope (i.e. to manage taxable income downwards without simultaneously decreasing financial accounting) is actually exploited. Since the newly introduced tax reporting discretion results in earlier recognition of tax expenses, the resulting timing effect reverses over time. In line with this, we observe that, from 2011 onwards, total book-tax differences once again become negative.

Mills and Newberry (2001) posit that the incentive to decrease taxable income relative to book income depends on a firm's profitability. In fact, firms accruing losses are unable to benefit from (further) negative earnings adjustments. By contrast, they may report in a way which delays advantageous tax accounting to profitable periods. Accordingly, we partition our sample into profitable and loss-making firms in order to assess differences in reporting behavior.

As Figure 1 reveals, we indeed find quite opposite effects for the two types of firms. While profitable firms on average exhibit a positive book-tax difference in 2010 (book income exceeds tax income), loss-making firms accrue the largest negative difference in that year. In the subsequent years, the overall book-tax differences of profitable and unprofitable firms converge again.

To gain insights into the drivers of the observed effect, Table 4 displays book-tax income differences for single balance sheet positions separately. We again compare mean scaled book-tax differences over the pre-reform years to those of the post-reform years in order to disclose the changes induced by the change in conformity. For each balance sheet item we additionally report the number of observations with non-zero values and whether the change of the book-tax differences is significantly different from zero (Table 4). 
Table 4: Mean book-tax income differences, scaled by total assets, pre- and post-reform

\begin{tabular}{|c|c|c|c|c|c|c|c|}
\hline & \multicolumn{3}{|c|}{ Pre-reform } & \multicolumn{3}{|c|}{ Post-reform } & \multirow[b]{2}{*}{$\mathrm{p}$} \\
\hline & \# & $\begin{array}{l}\text { Mean } \\
(\%)\end{array}$ & $\mathrm{Sd}$ & $\#$ & $\begin{array}{l}\text { Mean } \\
(\%)\end{array}$ & $\mathrm{Sd}$ & \\
\hline $\begin{array}{l}\text { Fixed assets } \\
\text { Intangible assets }\end{array}$ & 45 & 0.08 & 0.0174 & 72 & 0.03 & 0.0148 & 0.7041 \\
\hline PPE & 74 & -0.21 & 0.0280 & 137 & 0.15 & 0.0256 & 0.1089 \\
\hline Financial assets & 83 & 0.93 & 0.0658 & 148 & -0.37 & 0.0526 & 0.0089 \\
\hline $\begin{array}{l}\text { Current assets } \\
\text { Inventories }\end{array}$ & 27 & 0.03 & 0.0087 & 40 & 0.03 & 0.0081 & 0.9464 \\
\hline $\begin{array}{l}\text { Receivables and other } \\
\text { assets }\end{array}$ & 124 & 0.18 & 0.0259 & 217 & 0.00 & 0.0240 & 0.3752 \\
\hline Securities & 5 & -0.01 & 0.0011 & 7 & 0.00 & 0.0006 & 0.1352 \\
\hline Special item & 7 & 0.005 & 0.0005 & 15 & 0.012 & 0.0018 & 0.5985 \\
\hline Provisions & 181 & -0.42 & 0.0290 & 302 & 0.03 & 0.0287 & 0.07 \\
\hline Liabilities & 75 & -0.43 & 0.0385 & 155 & 0.24 & 0.0486 & 0.0804 \\
\hline
\end{tabular}

Total number of observations: 580 (pre-reform: 225; post-reform: 355 )

Note: This table contains the number of observations with non-zero values, mean book-tax income differences and standard deviations for single balance sheet positions, separated for the pre- and post-reform period. In the last column, it is reported whether the change of the book-tax differences is significantly different from zero.

Most importantly, we find a negative mean income difference for PPE pre-reform, which becomes positive post-reform. The change in the book-tax income difference is almost significant at the $10 \%$ level. ${ }^{9}$ An (untabulated) assessment of the development of PPE-related book-tax income differences over the sample period reveals that the observed total effect is driven mainly by a comparably large positive book-tax difference in 2010 which becomes slightly negative in 2011 before once again turning positive in 2012. In contrast, book-tax differences are on average negative in the pre-reform years. Importantly, one has to note that favorable declining balance tax depreciation was only available until 2010 in Germany. Hence, it seems reasonable to assume that the effect in 2011 would be less negative, had declining balance depreciation still been available in that year. Overall, our findings for PPE suggest that companies do opportunistically make use of tax depreciation rules.

Turning to inventories as a further balance sheet item offering new reporting discretion, we find a positive average income difference both pre- and post-reform (Table 4). We do not, however, observe a significant change in the two values. Likewise, there is only a minor change observable for the special item with reserve component. We therefore abstract from these two balance sheet items in our further analysis.

The remaining balance sheet positions are predominantly driven by deterministic deviations. We find the largest mean scaled book-tax differences (both pre- and post-reform) for financial assets. More specifically, the difference pre-reform is positive, post-reform it is negative; the change in the difference is significant. We attribute this change to impairments, which are regulated more restrictively in tax accounting, i.e. non-permanent impairments may be

\footnotetext{
At this point, we again point to the relatively small sample size. Moreover, it must be kept in mind that the reporting scope is solely related to new investments. As we would expect a comparably low level of investments in 2010 as a result of the financial crisis, we believe that the observed effect would be even more pronounced had 2010 been a year of economic expansion.
} 
recognized in financial accounting, whereas their recognition is forbidden in tax accounting. We observe a strongly negative pre-reform book-tax difference for provisions, which becomes positive and smaller in absolute terms post-reform. The same development is observed for liabilities. We find rather minor and insignificant effects for intangibles, receivables and securities.

To conclude, our descriptive analysis provides initial evidence that the discretionary scope in tax reporting, which arises from the decrease in book-tax conformity, is exercised. Furthermore, it suggests that deterministic differences are still material. Last, we acknowledge the fact that our sample period covers the financial crisis initiated in 2008. As Graham et al. (2012) note, the nature of findings pertaining to the direction of the book-tax income gap greatly depends on whether a study is carried out for a period of economic expansion or contraction. As we would expect fewer companies to be profitable and to carry out new investments, thus facing the possibility and incentive to engage in opportunistic tax reporting, in the years subsequent to the crisis, we argue that our results tend to be conservative. In other words, we believe that our results would be even more pronounced, had the sample period consistently been a period of economic expansion.

\section{Empirical analysis}

\subsection{Change of book-tax conformity, the book-tax income gap, and tax sheltering}

The descriptive evidence indicates that companies seem to make use of the newly introduced discretionary reporting scope. The following empirical analysis exploits the reform scenario econometrically in a difference-in-difference setting to substantiate the analysis.

\section{Hypothesis Development and Research Design}

While the BilMoG-Act basically serves as natural experiment in our research design, the reform, in general, affected all German corporations. Accordingly, we do not observe a natural control group (which is not affected by the reform at all) in our setting. The implied tax reporting leeway is, however, most probably only exercised by companies that have a clear incentive for tax sheltering (Chan et al. (2013), p. 7). Hence, profitable companies which can make efficient use of tax deductions are more likely to take advantage of opportunistic reporting opportunities (Manzon and Plesko (2002), p. 194; Wilson (2009), p. 985-987; Frank et al. (2009), p. 475). Loss-making companies, however, are expected not to face tax-related reporting incentives (Chan et al. (2010); Mills and Newberry (2001); Manzon and Plesko (2002)) as these companies do not pay any taxes in the current period. Furthermore, the tax benefits resulting from loss carry-forwards in future years are less certain (Mills and Newberry (2001), p. 4f.). We therefore hypothesize the following:

H 1: Book-tax income differences will increase for companies with incentives to use the new reporting discretion (profitable companies) compared to companies with no/less incentives (loss companies) subsequent to the implementation of the BilMoG-Act.

In order to test our hypothesis and to examine the effect of a decrease in book-tax conformity on reporting behavior, we essentially use a differences-in-differences methodology. In the basic regression equation, we estimate 
BTD $_{i, t}=\alpha_{0}+\alpha_{1}$ Profitable $_{i, t}+\alpha_{2}$ Reform $_{t}+\alpha_{3}$ Profitable $_{i, t} *$ Reform $_{t}+\gamma X_{i, t}+\varepsilon_{i, t}$

where $i$ indexes firms and $t$ indexes time. The dependent variable $B T D_{i, t}$ is defined as total book-tax income difference (balance-sheet differences) scaled by total assets. We compare outcomes before and after the reform for a group affected by the policy change (treatment) to a group not affected by the change (control). As only profitable companies have a clear incentive to use (and are therefore affected by) the new discretionary reporting scope, we take Profitable $_{i, t}$, a dummy variable which equals 1 for profitable firm-year observations (annual net income $>=0$ ) and 0 for firm-year observations with a loss (annual net income $<0$ ), as treatment variable. Profitable firms accordingly serve as treatment group; loss firms as control group in our analysis. As long as treatment and control groups are affected by time-varying confounding variables in a similar way, the difference in the two estimates will reflect the effect of the BilMoG-Act. In this regard, untabulated t-test results reveal that the change in the book-tax differences from year 2008 to 2009 is not significantly different for profitable and loss-making companies, which points to a similar development of book-tax differences in the pre-reform period. As the profitability of companies and therefore the incentive for tax sheltering might change from year to year, we basically consider a mover panel. ${ }^{10} \mathrm{We}$ further include a dummy variable Reform ${ }_{t}$ which equals 0 for years before the BilMoG-Act (20082009) and 1 for years after the introduction of the BilMoG-Act (2010-2012). To ensure a comparable number of observations in the pre- and post-period, we restrict our main analysis to the years 2008-2011. The key interaction term of interest, Profitable ${ }_{i, t}{ }^{*}$ Reform $_{t}$, equals one for profitable firm-year observations starting in 2010, and zero otherwise. The coefficient $\alpha_{3}$ represents the differences-in-differences estimator of introducing tax sheltering opportunities. Given that only companies with incentives are expected to make use of the new discretionary reporting scope, book-tax differences should comparatively increase in the treatment group subsequent to the implementation of the BilMoG-Act. We therefore expect $\alpha_{3}$ to be positive $\left(\alpha_{3}>0\right)$.

In addition, we include several firm-level control variables $\left(X_{i, t}\right)$ which possibly influence the reporting gap. First, we add those balance sheet items for which new discretionary leeway is expected following the introduction of the BilMoG-Act: $P P E_{i, t}$ (PPE reported in financial statements scaled by total assets) and Inventories ${ }_{i, t}$ (inventories reported in financial statements scaled by total assets). ${ }^{11}$ In addition, we include variables for which general substantive (mainly deterministic) differences between tax and financial accounting regulations in Germany exist. Following the descriptive analysis, and in view of previous research findings, ${ }^{12}$ we include Financials $s_{i, t}$ (financial assets reported in financial statements scaled by total assets), Provisions ${ }_{i, t}$ (provisions reported in financial statements scaled by total

10 For a detailed description of differences-in-differences analysis for cross-sections, mover and no-mover panels see Lee/Kang (2006). Moreover, the number of loss-firms per year is rather constant over the sample period and seems, therefore, not to be systematically influenced by the financial crisis.

11 We ignore the special item with reserve component in our empirical analysis due to materiality reasons; the descriptive analysis has shown that only approx. $4 \%$ of firms in our sample recognize this balance sheet item. Furthermore, following the introduction of the BilMoG-Act, recognition is prohibited in financial accounts.

12 See Zinn and Spengel (2012), Evers et al. (2014). 
assets) as well as Leverage ${ }_{i, t}{ }^{13}$ (ratio of debt to equity capital). Furthermore, we add the dummy variable Reorganization ${ }_{i, t}$ which equals 1 if the firm has been reorganized within the last 5 years and 0 otherwise. The rationale behind this is that, according to the German Tax Reorganization Act (UmwStG) ${ }^{14}$, book-tax conformity is not required in privileged reorganizations, which may further increase the book-tax income gap. Finally, we include two firm characteristic variables. These are $S_{i z e}$ (natural logarithm of total assets reported in financial statements) and Liquidity $_{i, t}$ (ratio of current assets to accounts payable). The mentioned variables, in particular Liquidity and Leverage, are also intended to control for factors that potentially determine participation, i.e. the probability of a company being profitable or not in a given year, and shall therefore alleviate concerns about sample selection.

Table 5 in the Appendix provides descriptive statistics for our regression variables on a pooled basis as well as separated into data relating to the pre- and post-reform periods. The correlations among the explanatory variables (see correlation matrix in Table 6 in the Appendix) do not provide any indication of an unacceptable level of multicollinearity in the data. ${ }^{15}$

\section{Results}

Table 7 presents the results for regression equation (1).

3 Leverage also constitutes a proxy for a firm's general capital structure (Chan et al. (2013)).

14 For more details see Zinn and Spengel (2012), p. 17.

15 According to Farrar and Glauber (1967) harmful levels of multicollinearity are not present until bivariate correlations exceed 0.8 . 
Table 7: Regression results

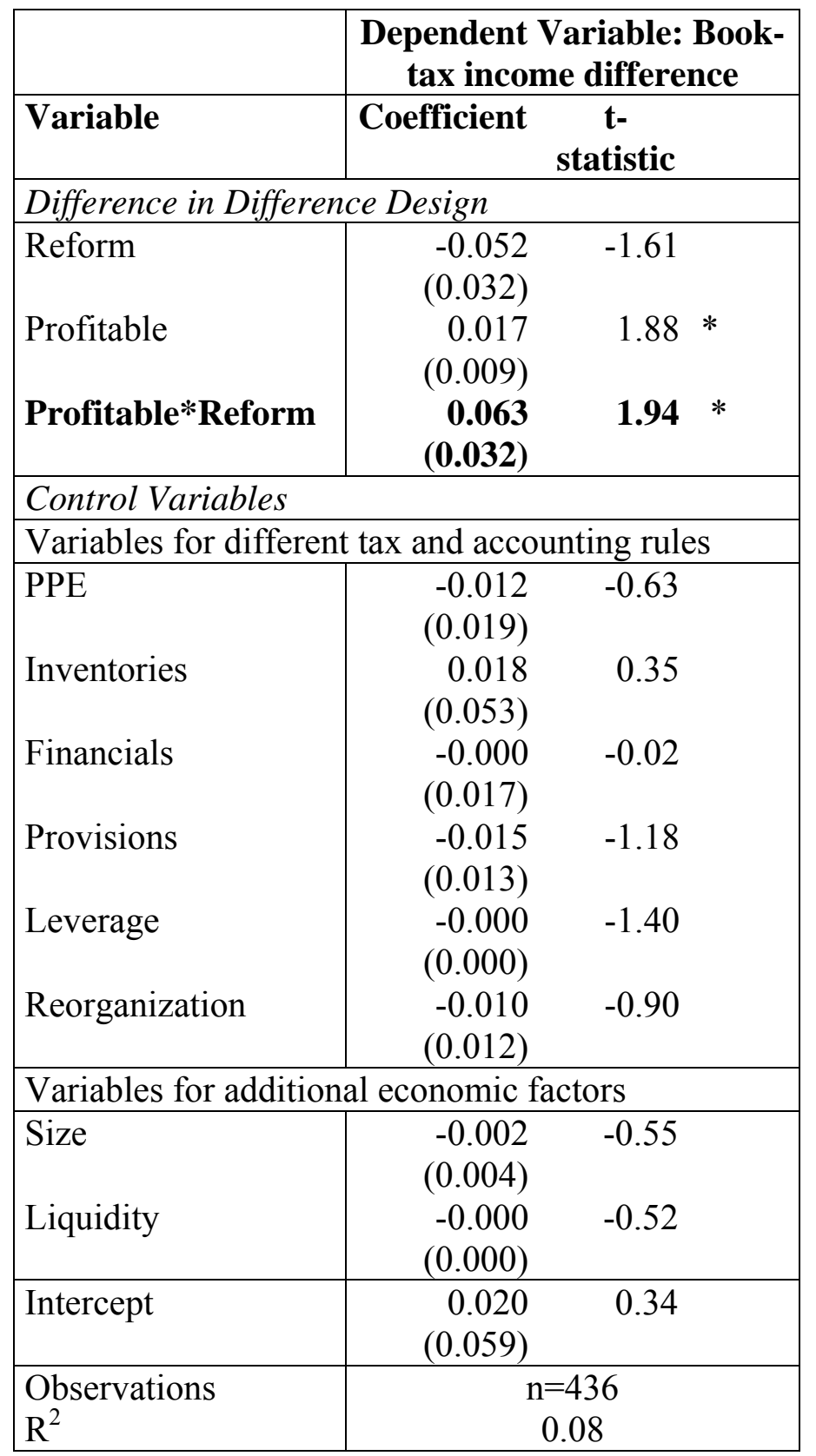

Note: This table presents the regression results using OLS. The dependent variable is BTD (income) scaled by total assets. Robust standard errors are shown in parentheses below coefficients. *,**,*** represent significance levels at $10 \%, 5 \%$ and $1 \%$ respectively.

We obtain a positive and statistically significant coefficient estimate $\left(\alpha_{3}\right)$ for the interaction term (Profitable*Reform) in line with Hypothesis 1. Specifically, the effect of the treatment group amounts to 0.011 (Reform (-0.053) + Profitable*Reform (0.063)). This implies that the opening of new tax reporting scope significantly increased book-tax income differences for those companies that have a clear incentive for tax sheltering (profitable firms), relative to those companies without incentive (loss firms). They indeed seem to exploit the new discretionary reporting leeway to manage taxable income downwards without simultaneously decreasing financial income. This finding is basically in line with Tang (2014) who also finds that high book-tax conformity generally deters tax sheltering. 
To assess the robustness of this finding, we examine further specifications and conduct additional tests (Table 8). First, we run our OLS regression with clustered standard errors at firm level (column (1)) instead of heteroscedasticity-robust standard errors to control for a potential correlation of outcomes within the unit/firms. ${ }^{16}$ To ensure that our results are not driven by differences between industries, ${ }^{17}$ we include industry fixed effects in column (2). The basic result $\left(\alpha_{3}\right)$ remains unchanged in the specifications. The untabulated industry dummies are not significant. While we consider only financial income profitability as treatment criteria in our main specification, we use a different definition including off-balance sheet adjustments in column (3). The intuition behind that is the following: Off-balance sheet adjustments can mainly be seen as a fixed non-manipulated component which has to be added to financial income anyway to end up with taxable income. Therefore, a company is only facing a clear balance sheet-based tax sheltering incentive if its financial income plus offbalance sheet adjustments is positive. If, however, off-balance sheet adjustments already fully eat up financial profits, there might be no clear incentive to further reduce taxable income even if a company is considered profitable according to its profit and loss statement. The basic result ( $\alpha_{3}$ positive and statistically significant) again holds for the alternative treatment definition. In column (4), we expand our basic sample by adding fiscal year 2012, thus accepting that there is no more symmetry in the number of pre- and post-reform observations. Whereas the difference-in-difference coefficient $\left(\alpha_{3}\right)$ is still statistically significant and positive, its magnitude decreases. This is in line with the assumption that the tax sheltering impact should be most prevalent directly after the introduction of the BilMoG-Act (fiscal year 2010) and should diminish and level out over time due to the reversal effect of temporary book-tax differences. In line with this argumentation, we include the lagged dependent variable $\left(B T D_{t-1}\right)$ as additional control in column (5) to test for a potential reversal effect. ${ }^{18}$ In this case as well, the main result $\left(\alpha_{3}\right)$ remains basically unchanged. Beyond that, it is striking that the effect of the treatment group (Reform + Profitable*Reform) remains fairly stable (and ranges between 0.09 and 0.013 ) in all five specifications. Finally, we conduct additional placebo difference-in-difference tests. In order to do so, we, first of all, define 2009 (the year previous to the introduction of the BilMoG-Act) as placebo reform year and run our basic regression (1) for the pre-reform period (years 2008-2009). Second, we use book-tax differences relating to provisions and liabilities as alternative outcome variables. These should not be affected by the intervention as related deviations are of deterministic nature and there has been no new reporting leeway with regard to these balance sheet items subsequent to the introduction of the BilMoG-Act. As expected, we do not determine a significant reform effect, i.e. an increase in book-tax differences for profitable companies in columns (6), (7) and (8) $\left(\alpha_{3}\right.$ not statistically and economically significant). This further demonstrates the validity of our findings.

16 OLS standard errors might understate the standard deviation of the DD estimator (Bertrand et al. (2004)).

17 Mills et al. (2002) and Plesko (2002) find, for example, that book-tax differences are greater in the financial and information industries.

18 See Manzon/Plesko (2002), p. 198; our panel is, therefore, restricted to the years 2009 to 2011 in this specification. 
Table 8: Robustness tests

\begin{tabular}{|c|c|c|c|c|c|c|c|c|}
\hline \multicolumn{9}{|c|}{ Dependent Variable: Book-tax income difference } \\
\hline & $\begin{array}{c}\text { (1) } \\
\text { Clustered SE } \\
\text { (firm level) }\end{array}$ & $\begin{array}{c}(2) \\
\text { Industry Fixed } \\
\text { Effects }\end{array}$ & $\begin{array}{l}\text { (3) } \\
\text { Profitability } \\
\text { incl. off }\end{array}$ & $\begin{array}{c}\text { (4) } \\
\text { Incl. } 2012\end{array}$ & $\begin{array}{c}(5) \\
\text { Lagged } \\
\text { dependent } \\
\text { variable }\end{array}$ & $\begin{array}{c}(6) \\
\text { Placebo Test: } \\
\text { Reform Year } \\
2009\end{array}$ & $\begin{array}{c}(7) \\
\text { Placebo Test: } \\
\text { Provisions }\end{array}$ & $\begin{array}{c}(8) \\
\text { Placebo Test: } \\
\text { Liabilities }\end{array}$ \\
\hline \multirow[t]{2}{*}{ Reform } & -0.052 & $-0.054 *$ & -0.033 & -0.017 & $-0.039 *$ & -0.002 & -0.001 & 0.006 \\
\hline & $(0.035)$ & $(0.033)$ & $(0.021)$ & $(0.015)$ & $(0.022)$ & $(0.015)$ & $(0.006)$ & $(0.008)$ \\
\hline \multirow[t]{2}{*}{ Profitable } & $0.017 * *$ & $0.019 * *$ & $0.016 *$ & $0.016^{*}$ & 0.011 & 0.015 & 0.004 & 0.003 \\
\hline & $(0.009)$ & $(0.009)$ & $(0.009)$ & $(0.008)$ & $(0.013)$ & $(0.011)$ & $(0.005)$ & $(0.008)$ \\
\hline \multirow[t]{2}{*}{ Profitable*Reform } & $0.063 *$ & $0.065 * *$ & $0.046 * *$ & $0.026 *$ & $0.048 * *$ & 0.009 & 0.007 & 0.003 \\
\hline & $(0.035)$ & $(0.033)$ & $(0.022)$ & $(0.016)$ & $(0.023)$ & $(0.016)$ & $(0.006)$ & $(0.010)$ \\
\hline BTD $_{t-1}$ & & & & & $\begin{array}{r}-0.157 \\
(0.140)\end{array}$ & & & \\
\hline \multirow[t]{2}{*}{ PPE } & -0.012 & -0.013 & -0.016 & -0.016 & -0.022 & -0.004 & & \\
\hline & $(0.018)$ & (0.019) & $(0.020)$ & $(0.017)$ & $(0.026)$ & $(0.018)$ & & \\
\hline \multirow[t]{2}{*}{ Inventories } & 0.018 & 0.017 & 0.021 & 0.020 & 0.052 & -0.019 & & \\
\hline & $(0.047)$ & $(0.052)$ & $(0.053)$ & $(0.042)$ & $(0.069)$ & $(0.026)$ & & \\
\hline \multirow[t]{2}{*}{ Financials } & -0.000 & -0.002 & -0.003 & -0.006 & 0.006 & -0.009 & & \\
\hline & $(0.015)$ & $(0.017)$ & $(0.016)$ & $(0.013)$ & $(0.021)$ & $(0.016)$ & & \\
\hline \multirow[t]{2}{*}{ Provisions } & -0.015 & -0.018 & -0.017 & $-0.024 * *$ & $-0.026 *$ & -0.005 & $-0.020 * *$ & \\
\hline & $(0.011)$ & $(0.016)$ & $(0.012)$ & $(0.010)$ & $(0.014)$ & $(0.014)$ & (0.009) & \\
\hline \multirow[t]{2}{*}{ Leverage } & $-0.000 *$ & $-0.000 *$ & $-0.000 *$ & -0.000 & -0.000 & -0.000 & -0.000 & -0.000 \\
\hline & $(0.000)$ & $(0.000)$ & $(0.000)$ & $(0.000)$ & $(0.000)$ & $(0.000)$ & $(0.000)$ & $(0.000)$ \\
\hline \multirow[t]{2}{*}{ Reorganization } & -0.010 & -0.011 & -0.013 & -0.012 & -0.012 & -0.003 & & \\
\hline & $(0.011)$ & $(0.012)$ & $(0.012)$ & $(0.010)$ & $(0.017)$ & $(0.012)$ & & \\
\hline \multirow[t]{2}{*}{ Size } & -0.002 & -0.002 & -0.001 & -0.001 & -0.004 & $0.005 *$ & -0.000 & -0.003 \\
\hline & $(0.003)$ & $(0.004)$ & $(0.004)$ & $(0.003)$ & $(0.005)$ & $(0.003)$ & $(0.001)$ & $(0.003)$ \\
\hline \multirow[t]{2}{*}{ Liquidity } & -0.000 & -0.000 & -0.000 & -0.000 & $-0.000 * *$ & -0.000 & -0.000 & -0.000 \\
\hline & $(0.000)$ & $(0.000)$ & $(0.000)$ & $(0.000)$ & $(0.000)$ & $(0.000)$ & $(0.000)$ & $(0.000)$ \\
\hline Intercept & $\begin{array}{r}-0.020 \\
(0.041)\end{array}$ & $\begin{array}{r}-0.013 \\
(0.068)\end{array}$ & $\begin{array}{r}0.009 \\
(0.059)\end{array}$ & $\begin{array}{r}0.003 \\
(0.048)\end{array}$ & $\begin{array}{r}0.070 \\
(0.078)\end{array}$ & $\begin{array}{r}-0.099 * * \\
(0.047)\end{array}$ & $\begin{array}{r}0.002 \\
(0.014)\end{array}$ & $\begin{array}{r}0.042 \\
(0.057)\end{array}$ \\
\hline $\begin{array}{l}\text { Observations } \\
\mathrm{R}^{2}\end{array}$ & $\begin{array}{c}\mathrm{n}=436 \\
0.08\end{array}$ & $\begin{array}{c}\mathrm{n}=436 \\
0.09\end{array}$ & $\begin{array}{c}\mathrm{n}=432 \\
0.07\end{array}$ & $\begin{array}{c}\mathrm{n}=534 \\
0.06\end{array}$ & $\begin{array}{c}\mathrm{n}=324 \\
0.11\end{array}$ & $\begin{array}{c}\mathrm{n}=212 \\
0.05\end{array}$ & $\begin{array}{c}\mathrm{n}=427 \\
0.04\end{array}$ & $\begin{array}{c}\mathrm{n}=427 \\
0.02\end{array}$ \\
\hline
\end{tabular}

Note: This table presents the regression results using OLS. Dependent variables are total scaled BTD (income) (1-6) or scaled BTD (income) relating to provisions (7) or to liabilities (8)

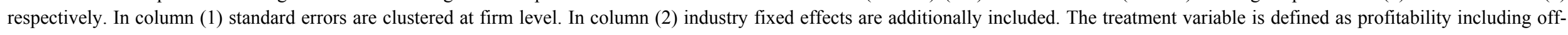
balance sheet adjustments in column (3). In column (4) the fiscal year 2012 is added to the sample. In column (5) the lagged dependent variable is included as additional control variable. In column (6) fiscal year 2009 is defined as placebo reform year. Robust standard errors are shown in parentheses below coefficients. ${ }^{*}, * *, * * *$ represent significance levels at $10 \%, 5 \%$ and $1 \%$ respectively. 


\section{Property, Plant and Equipment}

As shown before, PPE is the most relevant balance sheet item with new discretionary reporting leeway subsequent to the introduction of the BilMoG-Act in Germany. ${ }^{19}$ As depreciation schemes are generally recognized as one of the major instruments used for the management of taxable and book income in different directions and the descriptive analysis provides first evidence pointing into this direction as well, we rerun regression (1) with explicit focus on PPE. To that end, we use book-tax differences relating to PPE as alternative dependent variable and examine whether our finding also holds at single balance sheet level. We still control for the general level of PPE $\left(P P E_{t, i}\right)$ in the regression and

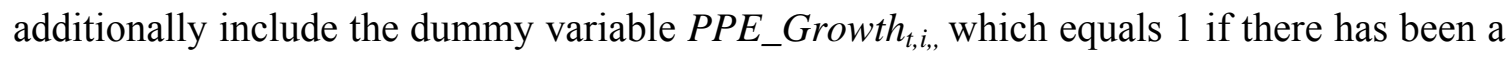
growth in the level of PPE $\left(P P E_{t, i}-P P E_{t-1, i}>=0\right)$ and 0 otherwise. Given that the reporting and depreciation options can basically only be applied to new investments, this variable is intended to capture the actual tax sheltering possibilities of a company. Finally, we again include the general economic controls described above: Leverage ${ }_{t, i}$, Size ${ }_{t, i}$ and Liquidity $_{t, i}$.

19 For more details see Section 3. 
Table 9: Regression results - PPE

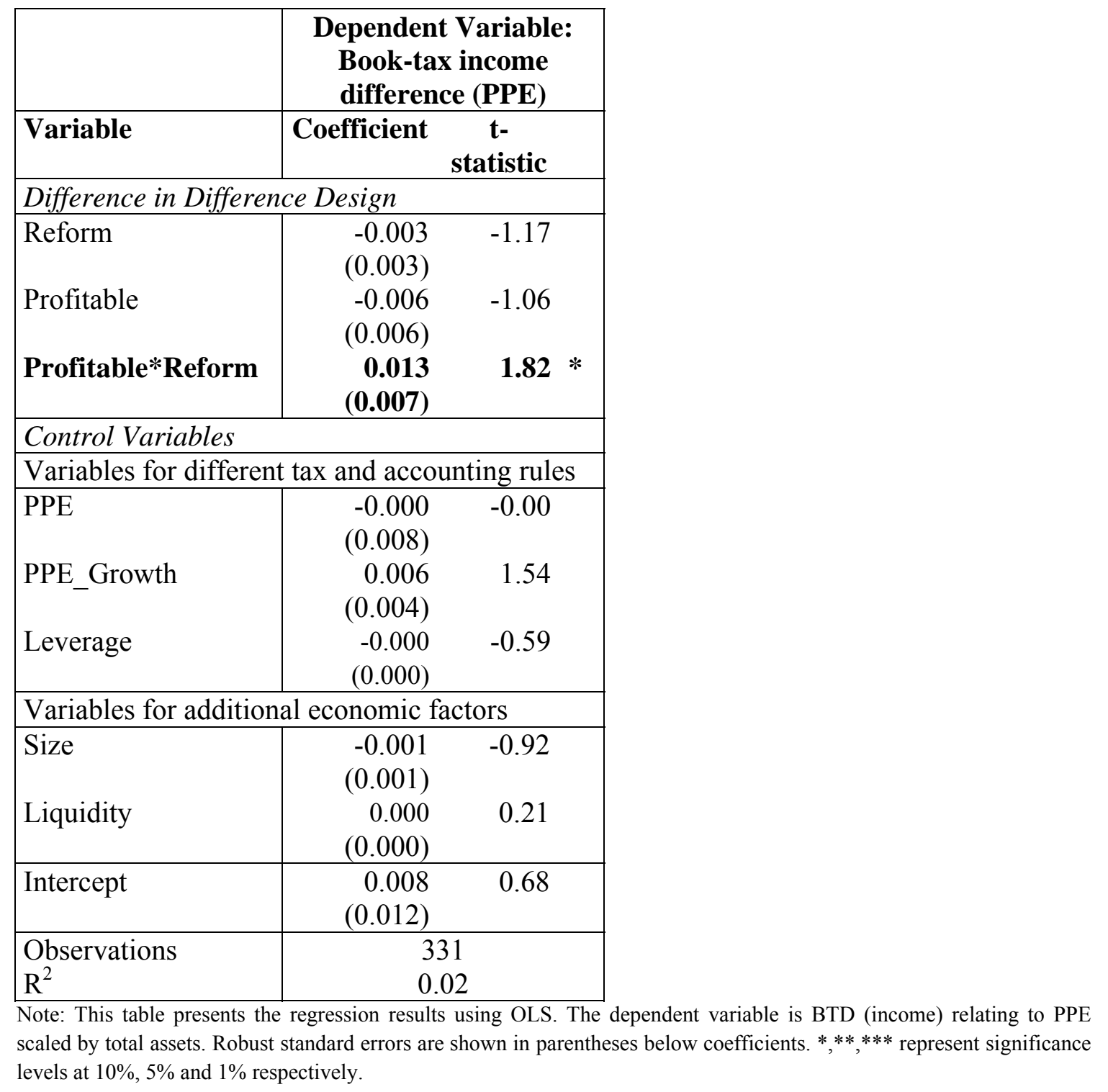

In this case as well, we obtain a positive and statistically significant difference-indifference estimate $\left(\alpha_{3}\right.$, Table 9$)$. In addition to that, the effect of the treatment group (0.01) still shows the same tendency as in our basic specification with total book-tax differences as dependent variable (0.011). This makes us confident that our findings are especially attributable to companies opportunistically making use of tax depreciation rules.

\section{Heterogeneous Reform Responses}

The ability and incentive to report opportunistically may be heterogeneous across firms and depend on particular company characteristics. 
First of all, the size of a company might be decisive. When it comes to the general association between firm size and tax sheltering or tax avoidance, the extant evidence is conflicting (Guenther et al. (1997), p. 242; Chan et al. (2013), p. 7). On the one hand, political power theory suggests that larger firms, because they have more resources available for manipulating political processes in their favor, develop expertise and experience in tax planning and structure complex transactions to minimize tax liabilities, pay proportionally lower income taxes than smaller firms (Scholes et al. (1992); Siegfried (1972)). More precisely, given that the BilMoG-Act resulted in the implementation of new documentation requirements with respect to the independent exercise of tax accounting options, and these additional costs are expected to decrease with the size of the company (fixed-cost component to keep ongoing registers), larger companies may have relatively lower tax sheltering costs. As a result of this, these firms could be more likely to be able to make use of the increased scope for discretionary reporting. On the other hand, political cost theory posits that larger firms are subject to higher political costs; they face greater public and regulatory scrutiny and are therefore less tax aggressive than smaller firms (Boynton et al. (1992); Watts and Zimmermann (1978); Zimmermann (1983)). Furthermore, large companies are more likely to operate multinationally and therefore to have access to alternative, international tax planning and profit shifting channels. This could induce these large companies to focus less on tax sheltering based on discretionary scope in national tax reporting (Davies et al. (2014)). Considering these conflicting theories, we hypothesize the following:

H2: The new reporting discretion will be used differently by companies depending on their size. Book-tax differences of small companies will therefore develop significantly different compared to book-tax differences of large companies subsequent to the implementation of the BilMoG-Act.

In order to test this hypothesis, we run our basic regression equation (1) only for companies generally facing a tax sheltering incentive, i.e. profitable companies, and with different treatment groups:

BTD $_{i, t}=\alpha_{0}+\alpha_{1}$ Treatment $_{i}+\alpha_{2}$ Reform $_{t}+\alpha_{3}$ Treatment $_{i} *$ Reform $_{t}+\gamma X_{i, t}+\varepsilon_{i, t}$

First of all, we conduct a median split and take $S i z e_{i}$, a dummy variable which equals 1 if the size of a company lies below the median (total assets reported on financial statements as of 2009) and 0 otherwise, as alternative treatment. Small firms accordingly serve as treatment group and large firms as control group in this specification. Given that small and large companies are expected to react differently to the new reporting incentives, book-tax differences should develop systematically different in the treatment group subsequent to the implementation of the BilMoG-Act. We therefore expect $\alpha_{3}$ to be significant, but are agnostic as to whether its sign is positive or negative $\left(\alpha_{3}><0\right)$. The control variables basically remain the same. Table 10 presents the results for regression equation (2). 
Table 10: Regression results - Heterogeneous reform response

\begin{tabular}{|c|c|c|c|c|}
\hline \multicolumn{5}{|c|}{ Dependent Variable: Book-tax income difference } \\
\hline & $\begin{array}{l}\text { (1) } \\
\text { Size }\end{array}$ & $\begin{array}{c}\text { (2) } \\
\text { Subsidiaries }\end{array}$ & $\begin{array}{c}(3) \\
\text { Direct parent } \\
\text { company }\end{array}$ & $\begin{array}{c}\text { (4) } \\
\text { Group parent } \\
\text { company }\end{array}$ \\
\hline Reform & $\begin{array}{r}0.000 \\
(0.005)\end{array}$ & $\begin{array}{l}-0.005 \\
(0.006)\end{array}$ & $\begin{array}{r}0.001 \\
(0.005)\end{array}$ & $\begin{array}{r}0.005 \\
(0.007)\end{array}$ \\
\hline \multirow[t]{2}{*}{ Treatment } & -0.010 & $-0.026 * * *$ & -0.005 & -0.017 \\
\hline & $(0.009)$ & $(0.010)$ & $(0.009)$ & $(0.011)$ \\
\hline Treatment*Reform & $\begin{array}{l}0.030 * \\
(0.015)\end{array}$ & $\begin{array}{r}0.036 * * \\
(0.014)\end{array}$ & $\begin{array}{r}0.020 \\
(0.012)\end{array}$ & $\begin{array}{r}0.028 \\
(0.018)\end{array}$ \\
\hline \multirow[t]{2}{*}{ PPE } & -0.007 & 0.009 & 0.000 & 0.006 \\
\hline & $(0.015)$ & $(0.013)$ & $(0.018)$ & $(0.019)$ \\
\hline \multirow[t]{2}{*}{ Inventories } & 0.029 & 0.036 & 0.033 & 0.039 \\
\hline & $(0.056)$ & $(0.056)$ & $(0.058)$ & $(0.061)$ \\
\hline \multirow[t]{2}{*}{ Financials } & -0.006 & 0.007 & 0.005 & 0.005 \\
\hline & $(0.012)$ & $(0.017)$ & $(0.019)$ & $(0.019)$ \\
\hline \multirow[t]{2}{*}{ Provisions } & -0.020 & -0.015 & -0.009 & -0.012 \\
\hline & $(0.015)$ & $(0.012)$ & $(0.013)$ & $(0.012)$ \\
\hline \multirow[t]{2}{*}{ Leverage } & -0.000 & 0.000 & -0.000 & -0.000 \\
\hline & $(0.000)$ & $(0.000)$ & $(0.000)$ & $(0.000)$ \\
\hline \multirow[t]{2}{*}{ Reorganization } & 0.013 & $0.017 * *$ & $0.018 *$ & $0.021 * *$ \\
\hline & $(0.008)$ & $(0.008)$ & $(0.010)$ & $(0.010)$ \\
\hline Size & & -0.004 & $\begin{array}{l}-0.004 \\
-0.004)\end{array}$ & -0.003 \\
\hline \multirow{2}{*}{ Liquidity } & -0.000 & $\begin{array}{r}(0.004) \\
-0.000\end{array}$ & $\begin{array}{r}(0.004) \\
-0.000^{*}\end{array}$ & $\begin{array}{r}(0.004) \\
-0.000\end{array}$ \\
\hline & $(0.000)$ & $(0.000)$ & $(0.000)$ & $(0.000)$ \\
\hline Intercept & $\begin{array}{r}-0.008 \\
(0.013)\end{array}$ & $\begin{array}{r}0.067 \\
(0.067)\end{array}$ & $\begin{array}{r}0.057 \\
(0.068)\end{array}$ & $\begin{array}{r}0.053 \\
(0.066)\end{array}$ \\
\hline Observations & $\mathrm{n}=353$ & $\mathrm{n}=345$ & $\mathrm{n}=322$ & $\mathrm{n}=304$ \\
\hline $\mathrm{R}^{2}$ & 0.04 & 0.05 & 0.04 & 0.04 \\
\hline
\end{tabular}

Note: This table presents the regression results using OLS. The dependent variable is BTD (income) scaled by total assets. Treatment variables are defined as dummies capturing the size (1), existence of subsidiaries (2) or nationality of the direct (3) or group parent company (4) respectively. Robust standard errors are shown in parentheses below coefficients. $*, * *, * * *$ represent significance levels at $10 \%, 5 \%$ and $1 \%$ respectively.

We obtain a positive and statistically significant coefficient estimate $\left(\alpha_{3}\right)$ for the interaction term (Size*Reform) in column (1) in line with Hypothesis 2, which we interpret as evidence for small companies exhibiting a systematic increase in book-tax differences compared to large companies subsequent to the reform. This implies that the new discretionary reporting scope has been mainly exploited by smaller companies. This seems to be contrary to the findings of Lisowsky (2010) and Chan et al. (2013) indicating that large companies are more likely to engage in tax sheltering.

To further validate our conjecture that large companies focus less on tax sheltering based on national tax reporting because they operate multinationally and have access to other tax planning (profit shifting) channels, we examine three additional specifications (Table 10). 
In order to do so, we use alternative treatment variables acting as proxy for the complexity and internationality of a company. In specification (2), we take a dummy variable which equals 1 if a company owns no subsidiaries and 0 otherwise (one or more subsidiaries) as treatment. In specifications (3) and (4), we define the treatment dummy as 1 if the direct parent or group parent company is domestic and as 0 if it is foreign. All of these specifications aim at identifying significant differences with regard to tax sheltering behavior depending on a company's group structure. We indeed find a positive and statistically significant coefficient $\left(\alpha_{3}\right)$ in column (2) implying that the reform systematically increased book-tax differences for those companies without subsidiaries (less complex firms) relative to those having subsidiaries (more complex firms). Even if we do not obtain statistically significant positive difference-in-difference coefficients in columns (3) and (4), the p-values of 0.109 and 0.119 are still remarkable, indicating that companies with domestic parent companies (national groups) tend to engage more in tax sheltering than companies with foreign parents (multinational groups). All of these findings corroborate the conjecture that complex and multinational corporations are less likely to engage in tax sheltering based on discretionary scope in national tax reporting.

In conclusion, we provide evidence that companies with definite tax sheltering incentives (profitable companies) indeed exploit the new reporting discretion following the decrease in book-tax conformity. More precisely, our results show that companies are opportunistically making use of tax depreciation rules. Hence, in that regard, our results support the position of proponents of increased book-tax conformity. Additionally, we find that smaller companies featuring less complex and predominantly national group structures have a greater tendency to engage in opportunistic tax reporting behavior.

\subsection{Change of book-tax conformity and the persistence of taxable and financial income}

Using individual financial and tax statements instead of consolidated accounts, it is most likely that the identified change in book-tax differences (Section 6.1) can be attributed to tax sheltering and not earnings management which rather occurs in consolidated accounts reported to the financial markets. To further rule out the influence of earnings management on the detected change in book-tax differences, we investigate whether the information content of reported taxable and financial income differs pre- and post-reform. The reasoning behind this is that increased tax sheltering is expected to deter the quality of reported taxable income while increased financial earnings management would deter the quality of reported financial income.

The persistence of earnings, i.e. the potential of predicting future earnings from current earnings, has been widely acknowledged in the literature as an appropriate measure of earnings quality (see Section 2.4). We therefore proceed along the lines of these studies (e.g. Hanlon (2005)) to oppose financial and taxable income persistence pre- and postreform. 
Specifically, we are interested in the effect of the possibility to independently exercise tax accounting options on earnings quality (persistence of taxable income), given that there was virtually no possibility for tax sheltering before the BilMoG-Act. Our data allows us to examine the persistence of taxable income which has been shown to entail economically valuable information, given its incremental explanatory power for stock returns (Hanlon et al. (2005)). In a second step, we also consider the impact of changed conformity on financial accounting earnings persistence. Comparing the two outcomes provides further insights whether tax or financial accounts are managed opportunistically and thus are responsible for the observed increase in book tax differences (see Section 6.1).

In addition to that, we provide evidence on the interplay between book-tax conformity, book-tax differences and earnings persistence. To the best of our knowledge, we are the first to do so.

As regards the persistence of taxable income, we ex ante expect that the newly emerged possibility for tax sheltering deters the information content of current taxable profits for one year ahead taxable profits. By contrast, given that earnings management is considered to be irrelevant in individual financial accounts and in light of the fact that financial accounting is less influenced by tax law subsequent to the BilMoG-Act, we expect no change or even an increase in the persistence of financial income as a consequence of the change in conformity. We therefore frame our third hypothesis as follows:

H3: The decrease in book-tax conformity arising from the implementation of the BilMoG-Act in Germany causes a decrease in the persistence of taxable income as a result of increased tax sheltering activity. By contrast, the persistence of financial accounting earnings remains unchanged or even improves.

\section{Research design}

We separately test for changes in the persistence of taxable income and financial accounting earnings. In doing so, we build on Hanlon (2005) and estimate for each income type the following OLS regression model for all firm-year observations:

$$
\begin{aligned}
\text { EARN }_{i, t+1}= & \beta_{0}+\beta_{1} E A_{R N_{i, t}}+\beta_{2} \text { BTD }_{i, t}+\beta_{3} \text { EARN }_{i, t} * \text { BTD }_{i, t}+\beta_{4} \text { Profitable }_{i, t} \\
& +\beta_{5} \text { EARN }_{i, t} * \text { Profitable }_{i, t}+\varepsilon_{i, t}
\end{aligned}
$$

$E A R N_{i, t}$ denotes either taxable income or financial accounting earnings. Essentially, Equation (3) estimates one-year ahead earnings (scaled by total assets), $E A R N_{i, t+1}$ as a function of current period's earnings (scaled by total assets) $E A R N_{i, t}$ in order to assess the general level of earnings persistence. ${ }^{20}$ In addition, we include $B T D_{i, t}$, which is the absolute

20 Therefore, our panel is restricted to the years 2008 to 2011 in this model. 
amount of the total book-tax income difference. Both variables are centered, i.e. the mean is subtracted from the predictors before fitting the regression model in order to increase interpretability. Additionally, we add the interaction of $E A R N_{i, t} * B T D_{i, t}$ in order to allow persistence to vary across different levels of book-tax differences. In this regard, a negative and significant coefficient of the interaction term would, for example, suggest that earnings persistence is lower where total book-tax differences are larger. We also incorporate Profitable $_{i, t}$, a dummy variable indicating whether annual net income is positive (1) or not (0) as well as the interaction term $E_{A R N_{i, t}} *$ Profitable $_{i, t}$ in order to account for the possibility that - in line with our analysis in 6.1 - incentives and observed effects may be different for profitable and loss firms. ${ }^{21}$ Finally, we include year-fixed effects.

We conduct a sample split to run estimation (3) for pre- and post-reform years separately. The idea is to compare the sign, size and significance levels, particularly of our major variables of interest. These are $E A R N_{i, t}$, used to determine whether the general level of persistence is altered by a change in book-tax conformity, and $E A R N_{i, t} * B T D_{i, t}$, used to provide answers to the question as to whether, depending on the degree of conformity, higher absolute book-tax differences are associated with a comparatively increased or decreased persistence.

\section{Results}

Table 11 presents the regression results of equation (3) for the persistence of taxable income.

21 For a similar approach see Atwood et al. (2010). 
Table 11: Regression results: Change of book-tax conformity and taxable income persistence

\begin{tabular}{|c|c|c|c|c|c|}
\hline & \multicolumn{2}{|c|}{ Pre-reform (2008-2009) } & \multicolumn{3}{|c|}{ Post-reform (2010-2011) } \\
\hline Variable & Coefficient & $\begin{array}{c}\mathbf{t}- \\
\text { statistic }\end{array}$ & Coefficient & $\begin{array}{c}\mathbf{t}- \\
\text { statistic }\end{array}$ & \\
\hline $\mathrm{EARN}_{\mathrm{i}, \mathrm{t}}$ & $\begin{array}{r}0.710 \\
(0.052)\end{array}$ & $13.70 * * *$ & $\begin{array}{r}0.501 \\
(0.125)\end{array}$ & 4.02 & $* * *$ \\
\hline BTD $_{i, t}$ & $\begin{array}{l}-0.221 \\
(0.078)\end{array}$ & $-2.83 * * *$ & $\begin{array}{r}0.032 \\
(0.068)\end{array}$ & 0.47 & \\
\hline $\mathrm{EARN}_{\mathrm{i}, \mathrm{t}} * \mathrm{BTD}_{\mathrm{i}, \mathrm{t}}$ & $\begin{array}{l}-0.532 \\
(0.404)\end{array}$ & -1.31 & $\begin{array}{l}-1.127 \\
(0.413)\end{array}$ & -2.73 & $* * *$ \\
\hline Profitable $_{i, t}$ & $\begin{array}{r}0.003 \\
(0.016)\end{array}$ & 0.21 & $\begin{array}{r}0.025 \\
(0.018)\end{array}$ & 1.45 & \\
\hline EARN $_{\mathrm{i}, \mathrm{t}} *$ Profitable $_{\mathrm{i}, \mathrm{t}}$ & $\begin{array}{l}-0.660 \\
(0.096)\end{array}$ & $-6.90 * * *$ & $\begin{array}{l}-0.036 \\
(0.131)\end{array}$ & -0.28 & \\
\hline Intercept & $\begin{array}{r}0.021 \\
(0.015)\end{array}$ & 1.36 & $\begin{array}{l}-0.013 \\
(0.017)\end{array}$ & -0.75 & \\
\hline $\begin{array}{l}\text { Observations } \\
\mathrm{R}^{2}\end{array}$ & & $\begin{array}{l}273 \\
4948\end{array}$ & & $\begin{array}{l}271 \\
1872\end{array}$ & \\
\hline
\end{tabular}

Note: This table presents OLS regression results for the analysis of taxable income persistence. The dependent variable is one-year ahead taxable income scaled by total assets. Robust standard errors are shown in parentheses below coefficients. $*, * *, * * *$ represent significance levels at $10 \%, 5 \%$ and $1 \%$ respectively.

Firstly, we find a positive and significant coefficient for $E A R N_{i, t}$ both pre- and post-reform which can be interpreted as the general persistence level of a company with average BTD. However, the coefficient and the significance level decrease, accordingly pointing to a decline in tax persistence induced by the decrease in book-tax conformity. We interpret this as an additional hint for companies engaging in tax sheltering which biases earnings and thus decreases their quality. Beyond this, our data also allows more specific conclusions to be drawn regarding the impact of book-tax differences on persistence. In that regard, we observe a significant and negative coefficient of the interaction term $\left(\beta_{3}\right)$, yet solely in the post-reform period. ${ }^{22}$ We interpret this such that higher book-tax differences induce a further reduction in taxable income persistence when book-tax conformity is low. Indeed, margins analysis of the interaction term ${ }^{23}$ for selected percentile values of BTD shows that the association between current period's earnings and one-period ahead earnings decreases if one compares the pre- to the post-reform period. For very large BTD $\left(99^{\text {th }}\right.$ percentile $)$ this relationship even turns negative in the post-reform era.

22 We do not find a direct impact of book-tax differences $\left(\beta_{2}\right)$ in the post-reform period.

23 Graphical results (marginsplots) are provided in Figure 2 in the Appendix. 
We conduct the same analysis for the persistence of financial accounting earnings and present results in Table 12.

Table 12: Regression results: Change of book-tax conformity and financial income persistence

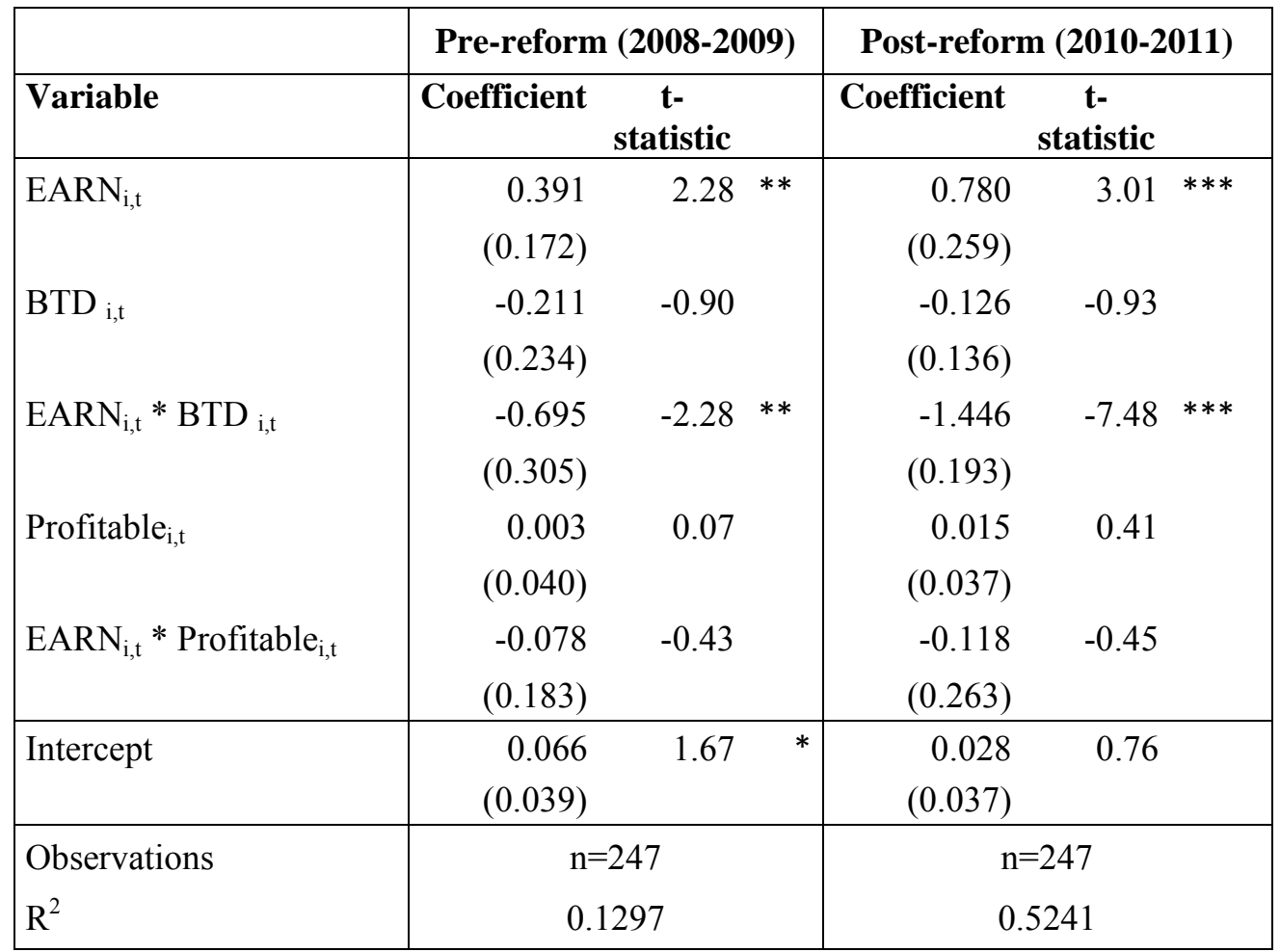

Note: This table presents OLS regression results for the analysis of financial accounting earnings persistence. The dependent variable is one-year ahead financial income scaled by total assets. Robust standard errors are shown in parentheses below coefficients. *,**,** represent significance levels at $10 \%, 5 \%$ and $1 \%$ respectively.

Again, we find a positive and significant coefficient for $E A R N_{i, t}$ both pre- and post-reform. Unlike for taxable income, however, the magnitude of $\beta_{1}$ rises subsequent to the introduction of the BilMoG-Act. In principle, this insight indicates an increase in earnings persistence induced by a decrease in book-tax conformity which is in line with empirical evidence previously provided (Hanlon et al. (2008), Atwood et al. (2010)). Specifically for our setting, this observation makes us confident that the observed book-tax differences in 2010 indeed relates to tax sheltering, rather than to distortive earnings management which expectedly would negatively impact on earnings quality. We therefore conclude that the BilMoG-Act did not induce earnings management in single financial accounts. Moreover, the evidence of increased financial accounting quality is in line with book-tax conformity opponents' claim that the two reporting lines serve different information needs and that earnings quality is superior when the determination of earnings is not influenced by tax law. Indeed, before enactment of the BilMoG, the reverse authoritative principle caused such an impact of tax reporting on financial accounts (see Section 3). 
As regards the general impact of book-tax differences, we do not find a direct impact of book-tax differences $\left(\beta_{2}\right)$ on one-year ahead earnings, whereas we do observe a significant and negative coefficient of the interaction term $\left(\beta_{3}\right)$. Once again we conclude that higher book-tax differences induce a reduction in earnings persistence. This is in line with Hanlon's (2005) finding and generally holds true for both pre- and post-BilMoG periods. However, the magnitude and the significance level of $\beta_{3}$ notably increases after the decrease in conformity. Despite the fact that we can observe a general increase in earnings persistence, we therefore conclude that large book-tax differences seem to have an even stronger negative impact on one-year ahead financial income if book-tax conformity decreases. This is also in line with margins analysis (Figure 2 in the Appendix) which shows that - unlike in the case of taxable income - the general association between current and one-period ahead earnings improves pre- vs. post-reform. Only if very large BTD (e.g. 99th percentile) are assessed, the earnings-future earnings relation is negative with the slope coefficient being even more negative post-reform.

To sum up, we observe a general decline in the persistence of taxable income as a consequence of the change in conformity. We attribute this decline in the quality of taxable income as an alternative earnings and performance figure to the distortive impact of the newly arisen scope for tax sheltering. As such, this finding supports the position of proponents of increased book-tax conformity. By contrast, our evidence suggests that the decrease in book-tax conformity induces a general increase in the persistence of financial accounting earnings. We take this as indication that there is no earnings management in individual accounts and thus conclude that that the general quality (informativeness) of financial accounting earnings has increased. Moreover, this insight is in line with the argumentation that both lines of reporting serve the information needs of different recipients and that the informativeness of earnings is enhanced when their determination is not affected by tax law. Moreover, this finding is in accordance with previous empirical literature predominantly suggesting that higher conformity deters overall financial accounting earnings quality. For both income types, higher book-tax differences adversely affect persistence. This effect is, however, more pronounced in a context of low conformity.

\section{Conclusion}

Exploiting a quasi-natural experiment (the BilMoG-Act) in Germany and using a sample of linked individual financial statements and actual tax return data, we explicitly examine the effects of a change in book-tax conformity on reporting behavior.

We show that the new reporting leeway resulting from a transition from a one-book to a more two-book-oriented accounting system indeed seems to be used. In our descriptive analysis, this is reflected in a positive total book-tax difference and a positive book-tax difference relating to PPE, constituting the balance sheet item with the largest scope for tax sheltering, in year 2010. Based on a difference-in-difference design, we demonstrate that 
profitable companies - facing a clear tax sheltering incentive - exhibit comparably higher book-tax differences subsequent to the decrease in conformity. This can particularly be traced back to book-tax differences relating to PPE and thus to companies making use of favorable tax depreciation rules. Furthermore, we find that small firms featuring less complex and predominantly national group structures are more likely to engage in opportunistic tax reporting behavior. Overall, these results support the position of proponents of increased book-tax conformity.

We also examine how the change in book-tax conformity affects the persistence of taxable and financial income. Our results suggest that a decrease in book-tax conformity induces a decline in the persistence of taxable income which we attribute to the distortive impact of the newly arisen tax sheltering options. In contrast to that, we observe a higher persistence of financial accounting earnings, thus corroborating our finding that earnings management is not driving our results. This finding is also in line with the arguments put forward by the opponents of increased conformity, who maintain that both accounting lines provide divergent information content parts of which are lost in case of an alignment. Moreover, our results suggest that large book-tax differences have a negative impact on one-yearahead (taxable and financial) income. This effect is, however, more pronounced in a context of decreased conformity and therefore yet another argument in favor of high conformity.

To sum up, we show that a switch from high to low book-tax conformity going along with accounting options creates room for opportunistic reporting which indeed is exploited for tax sheltering despite higher documentation costs. This finding speaks against such a shift towards a two-book system. At the same time, we show that detaching financial and taxable income increases the persistence of financial income, thus suggesting an increased information content of financial earnings in a two-book system. Essentially, the reduced persistence of taxable income post-reform, however, indicates that earnings quality deteriorates in a two-book system if incentives for opportunistic behavior are present. Hence, we conclude that a switch from high to low book-tax conformity increases opportunistic reporting behavior while not improving the information content with regard to those reported income numbers for which opportunistic reporting incentives are present. 


\section{References}

Ali, A. / Hwang, L. (2000), Country-Specific Factors Related to Financial Reporting and the Value Relevance of Accounting Data, Journal of Accounting Research, pp. 1-21.

Atwood, T.J. / Drake, M.S. / Myers, L.A. (2010), Book-tax conformity, earnings persistence and the association between earnings and future cash flows, Journal of Accounting and Economics, pp. 111-125.

Ayers, B. C. / Jiang, J. / Laplante, S.K. (2009), Taxable Income as a Performance Measure: The Effects of Tax Planning and Earnings Quality, Contemporary Accounting Research, pp. 15-54.

Badertscher, B.A. / Phillips, J.D. / Pincus, M. / Rego, S.O. (2009), Earnings Management Strategies and the Trade-Off Between Tax Benefits and Detection Risk: To Conform or Not to Conform?, The Accounting Review, pp. 63-97.

Bertrand, M. / Duflo, E. / Mullainathan, S. (2004), How much should we trust differences- in-differences estimates?, The Quarterly Journal of Economics, pp. 249-275.

Blaylock, B. / Shevlin, T. / Wilson, R. (2012), Tax avoidance, large positive book-tax differences, and earnings persistence, The Accounting Review, pp.91-120.

Blaylock, B. / Gaertner, F. / Shevlin, T. (2015), The association between book-tax conformity and earnings management, Review of Accounting Studies, pp. 141-172.

Boynton, C. / Dobbins, P. / Plesko, G. (1992), Earnings management and the corporate alternative minimum tax, Journal of Accounting Research, pp. 131-153.

Chan, K.H. / Lin, K.Z. / Mo, P. (2010), Will a Departure from Tax-based Accounting encourage Tax Noncompliance? Archival Evidence from a Transition Economy, Journal of Accounting and Economics, pp. 58-73.

Chan, K.H. / Lin, K.Z. / Tang, F. (2013), The Effects of Book-Tax Conformity, Financial Reporting Incentives, and Firm Size, Journal of International Accounting Research, pp. 125.

Coppens, L. and Peek. E. (2005), An analysis of earnings management by European private Firms, Journal of International Accounting, Auditing and Taxation, 14, 1-17.

Davies, R. B. / Martin, J. / Parenti, M. / Toubal, F. (2014), Knocking on Tax Haven's Door: Multinational Firms and Transfer Pricing, CESifo Working Paper No. 5132.

Dechow, P. / Ge, W. / Schrand, C. (2010), Understanding earnings quality: a review of the proxies, their determinants and their consequences, Journal of Accounting and Economics, pp. 344-401. 
Desai, M.A. (2003), The Divergence between Book Income and Tax Income, Tax Policy and the Economy, pp. 169-206.

Desai, M.A. (2005), The Degradation of Reported Corporate Profits, The Journal of Economic Perspectives, pp. 171-192.

Desai, M.A. / Dharmapala, D. (2006), Corporate Tax Avoidance and High Powered Incentives, Journal of Financial Economics, pp. 145-179.

Deutscher Bundestag (2008), Entwurf eines Gesetzes zur Modernisierung des Bilanzrechts, Bundestag Drucksache 16/10067 v. 30.07.2008.

Dhaliwal, D. / S. Wang (1992), The effect of book income adjustment in the 1986 Alternative Minimum Tax on corporate financial reporting, Journal of Accounting and Economics, pp. 7-26.

Evers, M.T. / Finke, K. / Matenaer, S. / Meier, I. / Zinn, B. (2014), Evidence on Booktax Differences and Disclosure Quality Based on the Notes to the Financial Statements, ZEW Discussion Paper.

Farrar, D. / Glauber, R. (1967), Multicollineearity in Regression Analyses the Problem Revisited, Review of Economics and Statistics, pp. 92-107.

Frank, M.M. / Lynch, L. / Rego, S.O. (2009), Tax Reporting Aggressiveness and Its Relation to Aggressive Financial Reporting, The Accounting Review, pp. 467-496.

Graham, J.R. / Raedy, J.S. / Shackelford, D.A. (2012), Research in accounting for income taxes, Journal of Accounting and Economics, pp. 412-434.

Guenther, D. / Maydew, E. / Nutter, S. (1997), Financial Reporting, Tax costs, and BookTax Conformity, Journal of Accounting and Economics, pp. 225-248.

Guenther, D.A. / Young, D. (2000), The association between financial accounting measures and real economic activity: a multinational study, Journal of Accounting and Economics, pp. 53-72.

Hanlon, M. (2003), What Can We Infer about a Firm's Taxable Income from Its Financial Statements?, National Tax Journal, pp. 831-863.

Hanlon, M. (2005), The Persistence and Pricing of Earnings, Accruals, and Cash Flows When Firms Have Large Book-Tax Differences, The Accounting Review, pp. 137-166.

Hanlon, M. / Shevlin, T. (2005), Book-Tax Conformity for Corporate Income: An Introduction to the Issues, Tax Policy and the Economy, pp. 101-134. 
Hanlon, M. / Laplante, S.K. / Shevlin, T. (2005), Evidence for the Possible Information Loss of Conforming Book Income and Taxable Income, Journal of Law and Economics, pp. 407-442.

Hanlon, M. / Maydew, E.L. / Shevlin, T. (2008), An unintended consequence of book-tax conformity: A loss of earnings informativeness, Journal of Accounting and Economics, pp. 294-311.

Hanlon, M. / Krishnan, G. / Mills, L. (2009), Do auditors use the information reflected in book-tax differences?, Working Paper.

Hanlon, M. / Maydew, E. (2009), Book-tax conformity: implications for multinational firms, National Tax Journal, pp. 127-153.

Hanlon, M. / Heitzman, S. (2010), A review of tax research, Journal of Accounting and Economics, pp. 127-178.

Harris, T. / Lang, M. / Moeller, H.P. (1994), The Value Relevance of German Accounting Measures: An Empirical Analysis, Journal of Accounting Research, pp. 187-209.

Hung, M. (2001), Accounting standards and value relevance of financial statements: An international analysis, Journal of Accounting and Economics, pp.401-420.

Joos, P. / Pratt, J. / Young, S. (2000), Book-Tax Differences and the pricing of earnings, Working Paper, Massachusetts Institute of Technology

Lamb, M. / Nobes, C. / Roberts, A. (1998), International Variations in the Connections Between Tax and Financial Reporting, Accounting and Business Research, pp. 173-188.

Lee, M. / Kang, C. (2006), Identification for difference in differences with cross-section and panel data, Economics Letters, pp. 270-276.

Leuz, C. / Nanda, D. / Wysocki, P. (2003), Earnings management and investor protection: an international comparison, Journal of Financial Economics, pp. 505-527.

Lev, B. / Nissim, D. (2004), Taxable Income, Future Earnings, and Equity Values, The Accounting Review, pp. 1039-1074.

Lisowsky, P. (2009), Inferring U.S. Tax Liability from Financial Statement Information, The Journal of the American Taxation Association, pp. 29-63.

Lisowsky, P. (2010), Seeking Shelter: Empirically Modelling Tax Shelters Using Financial Statement Information, The Accounting Review, pp. 1693-1720.

Manzon, G. / Plesko, G.A. (2002), The relation between financial and tax reporting measures of income, The Law Review, pp. 175-214. 
McClelland, J. / Mills, L. (2007), Weighing benefits and risks of taxing book income, Tax Notes International, pp. 779-787.

Mills, L.F. (1996), Corporate Tax Compliance and Financial Reporting, National Tax Journal, pp. 421-435.

Mills, L.F. (1998), Book-Tax Differences and Internal Revenue Service Adjustments, Journal of Accounting Research, pp. 343-356.

Mills, L.F. / Newberry, K.J. (2001), The Influence of Tax and Nontax Book-Tax Reporting Differences: Public and Private Firms, The Journal of the American Taxation Association, pp. 1-19.

Mills L.F. / Newberry, K.J. / Trautman, W. (2002), Trends in book-tax income and balance sheet differences, Tax Notes International, pp. 1109-1124.

Philips, J. / Pincus, M. / Rego, S. (2003), Earnings Management: New Evidence Based on Deferred Tax Expense, The Accounting Review, pp. 491-521.

Plesko, G.A. (2002), Reconciling Corporation Book and Tax Net Income, Tax Years 19961998, Statistics of Income Bulletin, pp. 111-132.

Plesko, G.A. (2007), Estimates of the Magnitude of Financial and Tax Reporting Conflicts, SSRN Working Paper.

Salbador, D. and V. Vendrzyk, V. (2012). The effect of book-tax conformity on tax and financial reporting aggressiveness: A longitudinal study, Working paper, Virginia Tech University and University of Richmond.

Schön, W. (2005), The Odd Couple: A Common Future for Financial and Tax Accounting?, Tax Law Review, pp. 111-148.

Scholes, M. / Wilson, G. / Wolfson, M. (1992), Firms' responses to anticipated reductions in tax rates: the Tax Reform Act of 1986, Journal of Accounting Research, pp. 161-185.

Seidman, J.K. (2010), Interpreting the Book-Tax Income Gap as Earnings Management or Tax Sheltering, McCombs Research Paper.

Shaviro, D. (2009), Internationalization of Income Measures and the U.S. Book-Tax Relationship, National Tax Journal, pp. 155-167.

Siegfried, J. (1972), The relationship between economic structure and the effect of political influence: Empirical evidence from the federal corporation income tax program, Dissertation, University of Wisconsin.

Tang, T. (2014), Does Book-Tax Conformity Deter Opportunistic Book and Tax Reporting? An International Analysis, Working Paper. 
Watrin, C. / Ebert, N. / Thomsen, M. (2014), Book-Tax Conformity and Earnings Management: Insights from European One- and Two-Book System, The Journal of the American Taxation Association, pp. 55-89.

Watts R.L. / Zimmermann, J.L. (1978), Toward a positive theory of determination of accounting standards, The Accounting Review, pp. 112-134.

Whitaker, C. (2005), Bridging the Book-Tax Accounting Gap, The Yale Law Journal, pp. 680-726.

Wilson, R.J. (2009), An Examination of Corporate Tax Shelter Participants, The Accounting Review, pp. 969-999.

Zimmermann, J. (1983), Taxes and firm size, Journal of Accounting and Economics, pp. 119-149.

Zinn, B. / Spengel, C. (2012), Book-tax Conformity: Empirical Evidence from Germany, ZEW Discussion Paper. 


\section{Appendix}

Table 1: Overview of authoritative principle pre- and post-BilMoG

\begin{tabular}{|c|c|c|c|}
\hline $\begin{array}{l}\text { Commercial } \\
\text { code }\end{array}$ & Tax law & Pre-BilMoG & Post-BilMoG \\
\hline $\begin{array}{l}\text { Compulsory } \\
\text { regulation }\end{array}$ & No regulation & $\mathrm{BS}=\mathrm{TBS}$ authoritative principle & $\mathrm{BS}=\mathrm{TBS}$ authoritative principle \\
\hline $\begin{array}{l}\text { Compulsory } \\
\text { regulation }\end{array}$ & Option & $\begin{array}{l}\mathrm{BS}=\mathrm{TBS} \text { authoritative principle (pseudo } \\
\text { option) }\end{array}$ & $\begin{array}{l}\mathrm{BS}=/ \neq \mathrm{TBS} \text { (abolishment of reverse } \\
\text { authoritative principle) }\end{array}$ \\
\hline $\begin{array}{l}\text { Compulsory } \\
\text { regulation }\end{array}$ & $\begin{array}{l}\text { Compulsory } \\
\text { regulation }\end{array}$ & $\begin{array}{l}\mathrm{BS}=/ \neq \text { TBS precedence of tax law (departure } \\
\text { from authoritative principle) }\end{array}$ & $\begin{array}{l}\mathrm{BS}=/ \neq \text { TBS precedence of tax law (departure } \\
\text { from authoritative principle) }\end{array}$ \\
\hline Option & $\begin{array}{l}\text { Compulsory } \\
\text { regulation }\end{array}$ & $\begin{array}{l}\mathrm{BS}=/ \neq \text { TBS precedence of tax law (departure } \\
\text { from authoritative principle) }\end{array}$ & $\begin{array}{l}\mathrm{BS}=/ \neq \text { TBS precedence of tax law (departure } \\
\text { from authoritative principle) }\end{array}$ \\
\hline Option & No regulation & $\mathrm{BS}=/ \neq \mathrm{TBS}$ authoritative principle $*$ & $\mathrm{BS}=/ \neq$ TBS authoritative principle $*$ \\
\hline Option & Option & $\mathrm{BS}=\mathrm{TBS}$ reverse authoritative principle & $\begin{array}{l}\mathrm{BS}=/ \neq \mathrm{TBS} \text { (abolishment of reverse } \\
\text { authoritative principle) }\end{array}$ \\
\hline
\end{tabular}

Note: This table provides an overview of the impact of the (reverse) authoritative principle with regard to potential deviations between financial and tax accounting, pre- and postreform. 


\section{Table 2: Overview of accounting items with BTD pre- and post-BilMoG}

\section{Assets}

\begin{tabular}{|c|c|c|c|c|c|c|c|c|}
\hline \multirow[b]{3}{*}{ Balance sheet item } & \multirow[b]{3}{*}{$\begin{array}{l}\text { German GAAP pre- } \\
\text { BilMoG }\end{array}$} & \multirow[b]{3}{*}{$\begin{array}{l}\text { German GAAP post- } \\
\text { BilMoG }\end{array}$} & \multirow[b]{3}{*}{ Tax Balance Sheet } & \multicolumn{4}{|c|}{ Deviations } & \multirow{3}{*}{\begin{tabular}{|l|}
$\begin{array}{l}\text { divergence/ } \\
\text { convergence }\end{array}$ \\
$*$
\end{tabular}} \\
\hline & & & & \multicolumn{2}{|c|}{ Deviation } & \multicolumn{2}{|c|}{ deterministic/discretionary } & \\
\hline & & & & pre-BilMoG & post-BilMoG & $\begin{array}{l}\text { with regard to } \\
\text { financial } \\
\text { accounting }\end{array}$ & \begin{tabular}{|l|} 
with regard to \\
tax balance \\
sheet
\end{tabular} & \\
\hline \multicolumn{9}{|l|}{ Fixed Assets } \\
\hline \multicolumn{9}{|l|}{ Intangible assets } \\
\hline $\begin{array}{l}\text { Internally created } \\
\text { intangible assets }\end{array}$ & Capitalization prohibited & Option to capitalize & Capitalization prohibited & no & possible & discretionary & deterministic & divergence \\
\hline Derivative goodwill & Option to capitalize & Capitalization required & Capitalization required & possible & no & deterministic & deterministic & convergence \\
\hline \multicolumn{9}{|l|}{ Tangible assets } \\
\hline Buildings & $\begin{array}{l}\text { Subsequent costs of } \\
\text { acquisition: capitalization } \\
\text { required (irrespective of } \\
\text { distance of time and amount of } \\
\text { costs relative to initial } \\
\text { acquisition) }\end{array}$ & $\begin{array}{l}\text { Subsequent costs of } \\
\text { acquisition: capitalization } \\
\text { required (irrespective of } \\
\text { distance of time and amount of } \\
\text { costs relative to initial } \\
\text { acquisition) }\end{array}$ & $\begin{array}{l}\text { Expenses for } \\
\text { maintenance/modernisation } \\
\text { within } 3 \text { years after acquisition } \\
\text { and in excess of } 15 \% \text { of initial } \\
\text { expenses: capitalization } \\
\text { required }\end{array}$ & possible & possible & deterministic & deterministic & - \\
\hline Low-value assets & $\begin{array}{l}\leq 150 \text { EUR: immediately } \\
\text { expensed; or capitalization and } \\
\text { deprecation (useful life) } \\
>150 \text { EUR, } \leq 410 \text { EUR: } \\
\text { immediately expensed; or } \\
\text { capitalization and deprecation } \\
\text { (useful life); or pool } \\
\text { depreciation ( } 5 \text { years) (only if } \\
\text { not material) } \\
>410 \text { EUR, } \leq 1.000 \text { EUR: } \\
\text { capitalization and deprecation } \\
\text { (useful life); or pool } \\
\text { depreciation ( } 5 \text { years) (only if } \\
\text { not material) }\end{array}$ & $\begin{array}{l}\leq 150 \text { EUR: immediately } \\
\text { expensed; or capitalization and } \\
\text { deprecation (useful life) } \\
>150 \text { EUR, } \leq 410 \text { EUR: } \\
\text { immediately expensed; or } \\
\text { capitalization and deprecation } \\
\text { (useful life); or pool } \\
\text { depreciation ( } 5 \text { years) (only if } \\
\text { not material) } \\
>410 \text { EUR, } \leq 1.000 \text { EUR: } \\
\text { capitalization and deprecation } \\
\text { (useful life); or pool } \\
\text { depreciation ( } 5 \text { years) (only if } \\
\text { not material) }\end{array}$ & $\begin{array}{l}\text { <150EUR: immediately } \\
\text { expensed; or capitalization and } \\
\text { deprecation (useful life) } \\
>150 \text { EUR, } \leq 410 \text { EUR: } \\
\text { immediately expensed; or } \\
\text { capitalization and deprecation } \\
\text { (useful life); or pool } \\
\text { depreciation ( } 5 \text { years) } \\
>410 \text { EUR, } \leq 1.000 \text { EUR: } \\
\text { capitalization and deprecation } \\
\text { (useful life); or pool } \\
\text { depreciation ( } 5 \text { years) }\end{array}$ & no & possible & discretionary & discretionary & divergence \\
\hline Financial assets & & & & & & & & \\
\hline $\begin{array}{l}\text { Shares in affiliated } \\
\text { companies }\end{array}$ & & & & & & & & \\
\hline
\end{tabular}




\begin{tabular}{|c|c|c|c|c|c|c|c|c|}
\hline $\begin{array}{l}\text { Shares in partnerships } \\
\text { Recognition } \\
\text { Subsequent } \\
\text { measurement }\end{array}$ & $\begin{array}{l}\text { Acquisition costs } \\
\text { Permanent impairment: write- } \\
\text { down required; non-permanent } \\
\text { impairment: write-down } \\
\text { optional }\end{array}$ & $\begin{array}{l}\text { Acquisition costs } \\
\text { Permanent impairment: write- } \\
\text { down required; non-permanent } \\
\text { impairment: write-down } \\
\text { optional }\end{array}$ & $\begin{array}{l}\text { Distinct, divergent valuation } \\
\text { method ("mirror image } \\
\text { method") } \\
\text { Write-down prohibited }\end{array}$ & $\begin{array}{l}\text { possible (non- } \\
\text { permanent } \\
\text { impairment)/ } \\
\text { yes (permanent } \\
\text { impairment) }\end{array}$ & $\begin{array}{l}\text { possible (non- } \\
\text { permanent } \\
\text { impairment)/ } \\
\text { yes (permanent } \\
\text { impairment) }\end{array}$ & $\begin{array}{l}\text { deterministic } \\
\text { discretionary } \\
\text { (non- } \\
\text { permanent } \\
\text { impairment) } \\
\text { /deterministic } \\
\text { (permanent } \\
\text { impairment) }\end{array}$ & $\begin{array}{l}\text { deterministic } \\
\text { deterministic }\end{array}$ & - \\
\hline \multicolumn{9}{|l|}{ Current assets } \\
\hline \multicolumn{9}{|l|}{ Inventories } \\
\hline $\begin{array}{l}\text { Simplifying valuation } \\
\text { methods }\end{array}$ & $\begin{array}{l}\text { Fifo, Lifo, Hifo; weighted } \\
\text { average }\end{array}$ & Fifo, Lifo; weighted average & Lifo; weighted average & no & possible & discretionary & discretionary & divergence \\
\hline \multicolumn{9}{|l|}{ Receivables } \\
\hline Dividend receivables & $\begin{array}{l}\text { Capitalization required (under } \\
\text { certain conditions) }\end{array}$ & $\begin{array}{l}\text { Capitalization required (under } \\
\text { certain conditions) }\end{array}$ & Capitalization prohibited & yes & yes & deterministic & deterministic & - \\
\hline Bad debt allowance & $\begin{array}{l}\text { Permanent impairment: write- } \\
\text { down required; non-permanent } \\
\text { impairment: write-down } \\
\text { optional }\end{array}$ & $\begin{array}{l}\text { Permanent impairment: write- } \\
\text { down required; non-permanent } \\
\text { impairment: write-down } \\
\text { optional }\end{array}$ & $\begin{array}{l}\text { Permanent impairment: write- } \\
\text { down optional; non-permanent } \\
\text { impairment: write-down } \\
\text { prohibited }\end{array}$ & $\begin{array}{l}\text { no (permanent } \\
\text { impairment)// } \\
\text { possible (non- } \\
\text { permanent } \\
\text { impairment) }\end{array}$ & possible & discretionary & $\begin{array}{l}\text { deterministic } \\
\text { (non- } \\
\text { permanent } \\
\text { impairment)/ } \\
\text { discretionary } \\
\text { (permanent } \\
\text { impairment) }\end{array}$ & divergence \\
\hline \multicolumn{9}{|l|}{ Production costs } \\
\hline $\begin{array}{l}\text { Materials and } \\
\text { production overhead; } \\
\text { depreciation }\end{array}$ & Option to capitalize & Capitalization required & Capitalization required & possible & no & deterministic & deterministic & convergence \\
\hline $\begin{array}{l}\text { General administration } \\
\text { costs, expenses for } \\
\text { social purposes, } \\
\text { voluntary social } \\
\text { benefits, company } \\
\text { pension scheme } \\
\text { Interest }\end{array}$ & Option to capitalize & Option to capitalize & Option to capitalize & no & possible & discretionary & discretionary & divergence \\
\hline $\begin{array}{l}\text { Research and } \\
\text { distribution costs }\end{array}$ & Capitalization prohibited & Capitalization prohibited & Capitalization prohibited & no & no & deterministic & deterministic & - \\
\hline \multicolumn{9}{|l|}{ Depreciation } \\
\hline General principles & $\begin{array}{l}\text { Rational commercial judgment } \\
\text { (no statutory specification of } \\
\text { method); switch from } \\
\text { declining balance method to } \\
\text { straight line depreciation } \\
\text { possible }\end{array}$ & $\begin{array}{l}\text { Rational commercial judgment } \\
\text { (no statutory specification of } \\
\text { method); switch from } \\
\text { declining balance method to } \\
\text { straight line depreciation } \\
\text { possible }\end{array}$ & $\begin{array}{l}\text { Straight line (useful life; } \\
\text { indication: "AfA-Tables") or } \\
\text { unit-of-production method; } \\
\text { declining balance method } \\
\text { applicable only until } \\
31.12 .2010\end{array}$ & no & possible & discretionary & discretionary & divergence \\
\hline
\end{tabular}




\begin{tabular}{|c|c|c|c|c|c|c|c|c|}
\hline \multicolumn{9}{|l|}{ Fixed assets } \\
\hline Intangible assets & $\begin{array}{l}\text { Depreciation according to } \\
\text { expected useful life }(<20 \\
\text { years; straight line method } \\
\text { unless another method is better } \\
\text { suited to the usage pattern) } \\
\text { straight line ( } 4 \text { years) or } \\
\text { straight line (useful life) }\end{array}$ & $\begin{array}{l}\text { Depreciation according to } \\
\text { expected useful life }(<20 \\
\text { years; straight line method } \\
\text { unless another method is better } \\
\text { suited to the usage pattern) } \\
\text { straight line } 5 \text { years (otherwise } \\
\text { justification necessary) }\end{array}$ & Straight line, 15 years & possible & possible & $x^{2}$ & $\begin{array}{l}\text { deterministic } \\
\text { (method), } \\
\text { discretionary } \\
\text { (length of } \\
\text { useful life) } \\
\text { deterministic }\end{array}$ & - \\
\hline Tangible assets & Rational commercial judgment & Rational commercial judgment & $\begin{array}{l}\text { Straight line (useful life; } \\
\text { indication: "AfA-Tables") or } \\
\text { unit-of-production method; } \\
\text { declining balance method } \\
\text { applicable only until } \\
\text { 31.12.2010 }\end{array}$ & no & possible & discretionary & discretionary & divergence \\
\hline Buildings & Rational commercial judgment & Rational commercial judgment & Straight line (33-50 years) & possible & possible & discretionary & deterministic & - \\
\hline \multicolumn{9}{|l|}{$\begin{array}{l}\text { Exceptional } \\
\text { depreciation }\end{array}$} \\
\hline \multicolumn{9}{|l|}{ Fixed assets } \\
\hline $\begin{array}{l}\text { Non-permanent } \\
\text { impairment }\end{array}$ & $\begin{array}{l}\text { Write-down optional } \\
\text { (companies of certain legal } \\
\text { status: only in case of financial } \\
\text { assets) }\end{array}$ & $\begin{array}{l}\text { write-down optional (but } \\
\text { limited to financial assets) }\end{array}$ & Write-down prohibited & possible & $\begin{array}{l}\text { possible } \\
\text { (financial } \\
\text { assets) }\end{array}$ & discretionary & deterministic & - \\
\hline $\begin{array}{l}\text { Permanent impairment } \\
\text { Current assets }\end{array}$ & Write-down required & Write-down required & Write-down optional & no & possible & deterministic & discretionary & divergence \\
\hline $\begin{array}{l}\text { Non-permanent } \\
\text { impairment }\end{array}$ & $\begin{array}{l}\text { Write-down required ("strict } \\
\text { lowest value principle") }\end{array}$ & $\begin{array}{l}\text { Write-down required ("strict } \\
\text { lowest value principle") }\end{array}$ & Write-down prohibited & yes & yes & deterministic & deterministic & - \\
\hline Permanent impairment & $\begin{array}{l}\text { Write-down required ("strict } \\
\text { lowest value principle") }\end{array}$ & $\begin{array}{l}\text { Write-down required ("strict } \\
\text { lowest value principle") }\end{array}$ & Write-down optional & no & possible & deterministic & discretionary & divergence \\
\hline $\begin{array}{l}\text { Special tax } \\
\text { depreciation }\end{array}$ & $\begin{array}{l}\text { Reverse authoritative } \\
\text { principle: adoption of special } \\
\text { tax depreciation }\end{array}$ & $\begin{array}{l}\text { Abolishment of reverse } \\
\text { authoritative principle: no } \\
\text { adoption of special tax } \\
\text { depreciation }\end{array}$ & $\begin{array}{l}\text { Diverse, e.g. accelerated } \\
\text { depreciation (promotion of } \\
\text { SME); valuation discounts; } \\
\text { increased depreciation } \\
\text { (restored buildings) }\end{array}$ & no & possible & discretionary & discretionary & divergence \\
\hline \multicolumn{9}{|l|}{ Pre-paid expenses } \\
\hline $\begin{array}{l}\text { Tariffs/Excise } \\
\text { taxes/value added tax } \\
\text { on customer advances } \\
\text { Debt discount }\end{array}$ & Capitalization optional & Capitalization prohibited & Capitalization required & possible & possible & $\begin{array}{l}\text { deterministic } \\
\text { discretionary }\end{array}$ & $\begin{array}{l}\text { deterministic } \\
\text { deterministic }\end{array}$ & divergence \\
\hline
\end{tabular}

*Deviation: implied divergence or convergence of book and tax income? ( - : no change/no clear tendency) 


\section{Liabilities}

\begin{tabular}{|c|c|c|c|c|c|c|c|c|}
\hline \multirow[b]{3}{*}{ Balance sheet item } & \multirow[b]{3}{*}{$\begin{array}{l}\text { German GAAP pre- } \\
\text { BilMoG }\end{array}$} & \multirow[b]{3}{*}{$\begin{array}{l}\text { German GAAP post- } \\
\text { BilMoG }\end{array}$} & \multirow[b]{3}{*}{ Tax Balance Sheet } & \multicolumn{4}{|c|}{ Deviations } & \multirow{3}{*}{\begin{tabular}{|l|l|} 
divergence/ \\
convergence
\end{tabular}} \\
\hline & & & & \multicolumn{2}{|c|}{ Deviation } & \multicolumn{2}{|c|}{$\begin{array}{l}\text { deterministic/ } \\
\text { discretionary }\end{array}$} & \\
\hline & & & & pre-BilMoG & post-BilMoG & $\begin{array}{l}\text { with regard to } \\
\text { financial } \\
\text { accounting }\end{array}$ & $\begin{array}{l}\text { with regard to } \\
\text { tax balance } \\
\text { sheet }\end{array}$ & \\
\hline \multicolumn{9}{|l|}{ Equity } \\
\hline $\begin{array}{l}\text { Special item with } \\
\text { reserve component }\end{array}$ & Recognition optional & Recognition prohibited & \begin{tabular}{|l|} 
Recognition optional \\
(reinvestment reserve, subsidy \\
reserve, replacement reserve, \\
gains from confusion)
\end{tabular} & no & possible & - & discretionary & divergence \\
\hline \multicolumn{9}{|l|}{ Provisions } \\
\hline \multicolumn{9}{|l|}{ Pension provisions } \\
\hline Recognition & & & & & & & & \\
\hline $\begin{array}{l}\text { Pension provisions } \\
\text { (New provisions) }\end{array}$ & $\begin{array}{l}\text { Recognition required } \\
\text { (uncertain liability) }\end{array}$ & $\begin{array}{l}\text { Recognition required } \\
\text { (uncertain liability) }\end{array}$ & $\begin{array}{l}\text { Recognition required if } \\
\text { conditions fulfilled, otherwise } \\
\text { recognition prohibited }\end{array}$ & possible & possible & deterministic & deterministic & no change \\
\hline $\begin{array}{l}\text { Pension provisions } \\
\text { (Existing provisions) }\end{array}$ & Recognition optional & Recognition optional & $\begin{array}{l}\text { Recognition optional (as } \\
\text { German GAAP) }\end{array}$ & no & no & - & - & no change \\
\hline $\begin{array}{l}\text { Indirect commitments } \\
\text { from pension promise }\end{array}$ & Recognition optional & Recognition optional & Recognition prohibited & possible & possible & discretionary & - & no change \\
\hline \multicolumn{9}{|l|}{ Measurement } \\
\hline General measurement & $\begin{array}{l}\text { No requirement concerning } \\
\text { measurement, modified } \\
\text { discount value method }\end{array}$ & $\begin{array}{l}\text { No requirement concerning } \\
\text { measurement, possibly } \\
\text { transition to projected unit } \\
\text { credit method, no modified }\end{array}$ & $\begin{array}{l}\text { Modified discount value } \\
\text { method (proceedings for equal } \\
\text { distribution) }\end{array}$ & possible & possible & deterministic & deterministic & divergence \\
\hline $\begin{array}{l}\text { Consideration of } \\
\text { salary and pension }\end{array}$ & $\begin{array}{l}\text { Depending on economic } \\
\text { situation (following tax law) }\end{array}$ & Consideration required & Consideration prohibited & possible & yes & deterministic & deterministic & divergence \\
\hline Discounting & $\begin{array}{l}\text { Depending on economic } \\
\text { situation 3-6\% (following tax } \\
\text { law) }\end{array}$ & $\begin{array}{l}\text { Required, average market } \\
\text { interest rate of previous } 7 \\
\text { years, option for general fixing } \\
\text { at } 15 \text { years }\end{array}$ & Required, $6 \%$ & possible & possible & deterministic & deterministic & divergence \\
\hline
\end{tabular}




\begin{tabular}{|c|c|c|c|c|c|c|c|c|}
\hline Vacation provisions & $\begin{array}{l}\text { Consideration of pay increases } \\
\text { after balance sheet date, yearly } \\
\text { agreed-upon fringe benefits } \\
\text { such as bonuses, allocations to } \\
\text { pension provisions, } \\
\text { proportionate overhead costs; } \\
\text { for determining of daily rate: } \\
\text { actual working days usually } \\
220 \text { days per year }\end{array}$ & $\begin{array}{l}\text { Consideration of pay increases } \\
\text { after balance sheet date, yearly } \\
\text { agreed-upon fringe benefits } \\
\text { such as bonuses, allocations to } \\
\text { pension provisions, } \\
\text { proportionate overhead costs; } \\
\text { for determining of daily rate: } \\
\text { actual working days usually } \\
220 \text { days per year }\end{array}$ & $\begin{array}{l}\text { No consideration of pay } \\
\text { increases after balance sheet } \\
\text { date, yearly agreed-upon fringe } \\
\text { benefits such as bonuses, } \\
\text { allocations to pension } \\
\text { provisions, proportionate } \\
\text { overhead costs; } \\
\text { for determining of daily rate: } \\
\text { regular working days ( } 250 \\
\text { working days per year) }\end{array}$ & possible & possible & deterministic & deterministic & - \\
\hline \multicolumn{9}{|l|}{ Other provisions } \\
\hline \multicolumn{9}{|l|}{ Recognition } \\
\hline $\begin{array}{l}\text { Provisions for } \\
\text { contingent losses }\end{array}$ & Recognition required & Recognition required & Recognition prohibited & yes & yes & deterministic & deterministic & no change \\
\hline $\begin{array}{l}\text { Provisions for deferred } \\
\text { maintenance (catching } \\
\text { up within three } \\
\text { months) }\end{array}$ & Recognition required & Recognition required & $\begin{array}{l}\text { Recognition required, only for } \\
\text { liabilities against third parties }\end{array}$ & possible & possible & deterministic & deterministic & no change \\
\hline $\begin{array}{l}\text { Provisions for deferred } \\
\text { maintenance(catching } \\
\text { up after three months } \\
\text { but within the } \\
\text { following financial } \\
\text { year) }\end{array}$ & Recognition optional & Recognition prohibited & Recognition prohibited & possible & no & - & - & convergence \\
\hline $\begin{array}{l}\text { Provisions for } \\
\text { infringement of } \\
\text { patents, authority or }\end{array}$ & $\begin{array}{l}\text { If sufficiently concretized } \\
\text { recognition required, otherwise } \\
\text { prohibited }\end{array}$ & $\begin{array}{l}\text { If sufficiently concretized } \\
\text { recognition required, otherwise } \\
\text { prohibited }\end{array}$ & $\begin{array}{l}\text { Under certain conditions } \\
\text { recognition required, otherwise } \\
\text { prohibited }\end{array}$ & possible & possible & deterministic & deterministic & no change \\
\hline $\begin{array}{l}\text { Provisions for } \\
\text { anniversary bonuses }\end{array}$ & Recognition required & Recognition required & $\begin{array}{l}\text { Only under certain conditions } \\
\text { recognition required, otherwise } \\
\text { prohibited }\end{array}$ & possible & possible & deterministic & deterministic & no change \\
\hline $\begin{array}{l}\text { Provisions for costs to } \\
\text { be capitalized in future } \\
\text { periods }\end{array}$ & Recognition required & Recognition required & Recognition prohibited & yes & yes & deterministic & deterministic & no change \\
\hline $\begin{array}{l}\text { Provisions for } \\
\text { harmless disposal of } \\
\text { radioactive waste }\end{array}$ & Recognition required & Recognition required & Recognition prohibited & yes & yes & deterministic & deterministic & no change \\
\hline $\begin{array}{l}\text { Provisions that only } \\
\text { need to be fulfilled } \\
\text { when future earnings } \\
\text { or gains accrue }\end{array}$ & Recognition required & Recognition required & $\begin{array}{l}\text { Recognition prohibited, only } \\
\text { when earnings or gains accrue }\end{array}$ & yes & yes & deterministic & deterministic & no change \\
\hline
\end{tabular}




\begin{tabular}{|c|c|c|c|c|c|c|c|c|}
\hline \multicolumn{9}{|l|}{ Measurement } \\
\hline Future price and cost & 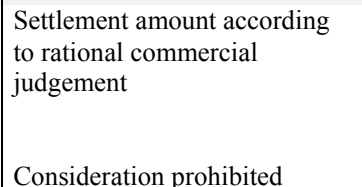 & 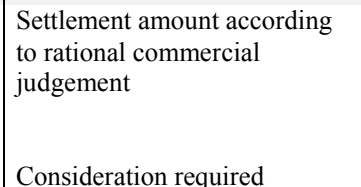 & Consideration prohibited & possible & 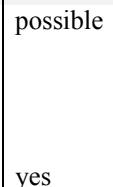 & $\begin{array}{l}\text { deterministic } \\
\text { (possibly } \\
\text { powers of } \\
\text { discretion: } \\
\text { discretionary) } \\
\text { deterministic }\end{array}$ & \begin{tabular}{|l|} 
deterministic \\
(possibly \\
powers of \\
discretion: \\
discretionary) \\
deterministic
\end{tabular} & no change \\
\hline $\begin{array}{l}\text { increases } \\
\text { Discounting (maturity } \\
>1 \text { year) }\end{array}$ & Prohibited & $\begin{array}{l}\text { Required, average market } \\
\text { interest rate of previous } 7 \text { years }\end{array}$ & Required, $5.5 \%$ & yes & possible & deterministic & & $\begin{array}{l}\text { no clear } \\
\text { tendency/conver } \\
\text { gence }\end{array}$ \\
\hline \multicolumn{9}{|l|}{ Liabilities } \\
\hline \multicolumn{9}{|l|}{ Recognition } \\
\hline $\begin{array}{l}\text { Liabilities that need } \\
\text { only be fulfilled when } \\
\text { future earnings or } \\
\text { gains accrue }\end{array}$ & $\begin{array}{l}\text { Recognition required (rational } \\
\text { commercial judgement) }\end{array}$ & $\begin{array}{l}\text { Recognition required (rational } \\
\text { commercial judgement) }\end{array}$ & $\begin{array}{l}\text { Recognition prohibited, only } \\
\text { when earnings or gains accrue }\end{array}$ & yes & yes & deterministic & deterministic & no change \\
\hline \multicolumn{9}{|l|}{ Measurement } \\
\hline General measurement & $\begin{array}{l}\text { Value at time of accrual or } \\
\text { higher repayment amount } \\
\text { respectively }\end{array}$ & Settlement amount & $\begin{array}{l}\text { (Discounted) settlement } \\
\text { amount }\end{array}$ & possible & possible & deterministic & deterministic & no change \\
\hline $\begin{array}{l}\text { Discounting (maturity } \\
>1 \text { year) }\end{array}$ & No present value estimate & No present value estimate & Required, $5.5 \%$ & yes & yes & deterministic & deterministic & no change \\
\hline $\begin{array}{l}\text { Reflection of } \\
\text { uncertainty }\end{array}$ & Rational commercial discretion & Rational commercial discretion & $\begin{array}{l}\text { Going-concern value, } \\
\text { consideration of probability } \\
\text { that only part of the liability } \\
\text { needs to be fulfilled }\end{array}$ & possible & possible & deterministic & deterministic & no change \\
\hline
\end{tabular}

* Deviation: implied divergence or convergence of book and tax income? ( - : no change/no clear tendency)

Note: This table lists (possible) deviations between financial and tax accounting at the level of single balance sheet items, pre- and post-reform. 
Table 5: Descriptive Statistics

\begin{tabular}{|l|c|c|c|}
\hline Variable & $\begin{array}{c}\text { Pooled } \\
\text { (2008-2012) }\end{array}$ & $\begin{array}{c}\text { Pre-BilMoG } \\
\mathbf{( 2 0 0 8 - 2 0 0 9 )}\end{array}$ & $\begin{array}{c}\text { Post-BilMoG } \\
\text { (2010-2012) }\end{array}$ \\
\hline BTD & -0.001 & -0.006 & 0.003 \\
Profitability & $(0.082)$ & $(0.071)$ & $(0.092)$ \\
PPE & 0.847 & 0.844 & 0.849 \\
& $(0.360)$ & $(0.363)$ & $(0.358)$ \\
Inventories & 0.142 & 0.147 & 0.137 \\
Financials & $(0.199)$ & $(0.201)$ & $(0.197)$ \\
Provisions & 0.113 & 0.109 & 0.118 \\
Leverage & $(0.169)$ & $(0.162)$ & $(0.176)$ \\
& 0.224 & 0.225 & 0.223 \\
Reorganization & $(0.322)$ & $(0.322)$ & $(0.321)$ \\
& 0.167 & 0.170 & 0.165 \\
Size & $(0.190)$ & $(0.191)$ & $(0.189)$ \\
& 20.005 & 16.327 & 23.656 \\
Liquidity & $(115.731)$ & $(85.228)$ & $(139.645)$ \\
& 0.188 & 0.214 & 0.163 \\
& $(0.391)$ & $(0.411)$ & $(0.370)$ \\
& 17.410 & 17.400 & 17.419 \\
& $(1.967)$ & $(1.942)$ & $(1.994)$ \\
& 126.377 & 226.554 & 27.933 \\
& $(2592.468)$ & $(3678.415)$ & $(181.622)$ \\
\hline
\end{tabular}

Note: This table displays the mean of the variables used in the regression analysis for the full sample (1) or a sample split for the years 2008-2009 pre-reform (2) and the years 2010-1012 post-reform (3) respectively. Standard errors are shown in parentheses. 
Table 6: Correlation Matrix

\begin{tabular}{|c|c|c|c|c|c|c|c|c|c|c|}
\hline & BTD & Profitability & PPE & Inventories & Financials & Provisions & Leverage & $\begin{array}{c}\text { Reorgani- } \\
\text { zation }\end{array}$ & Size & Liquidity \\
\hline BTD & 1.0000 & & & & & & & & & \\
\hline Profitability & $0.1005^{*}$ & 1.0000 & & & & & & & & \\
\hline PPE & -0.0246 & 0.0391 & 1.0000 & & & & & & & \\
\hline Inventories & 0.0503 & $0.1169^{*}$ & 0.0331 & 1.0000 & & & & & & \\
\hline Financials & -0.0460 & $-0.1274^{*}$ & $-0.3397^{*}$ & $-0.3139 *$ & 1.0000 & & & & & \\
\hline Provisions & -0.0327 & $0.1010^{*}$ & 0.0247 & 0.0214 & $-0.3800^{*}$ & 1.0000 & & & & \\
\hline Leverage & -0.0070 & 0.0066 & -0.0501 & -0.0017 & -0.0912 & 0.0541 & 1.0000 & & & \\
\hline Reorganization & -0.0868 & -0.0832 & -0.1063 & -0.0439 & -0.0430 & 0.0698 & -0.0602 & 1.0000 & & \\
\hline Size & $-0.0998^{*}$ & 0.0379 & $0.1700^{*}$ & $-0.1240 *$ & $0.2832 *$ & 0.0185 & -0.0305 & 0.0780 & 1.0000 & \\
\hline Liquidity & -0.0077 & -0.0883 & -0.0261 & -0.0299 & -0.0299 & -0.0343 & -0.0078 & -0.0191 & -0.0636 & 1.0000 \\
\hline
\end{tabular}

Note: This table displays the correlation between the variables used in the regression analysis. * represents a $1 \%$ significance level. 
Figure 2: Marginsplot analysis for the $50^{\text {th }}$ and $99^{\text {th }}$ percentile of BTD, pre-vs. postreform

Panel a: Taxable income
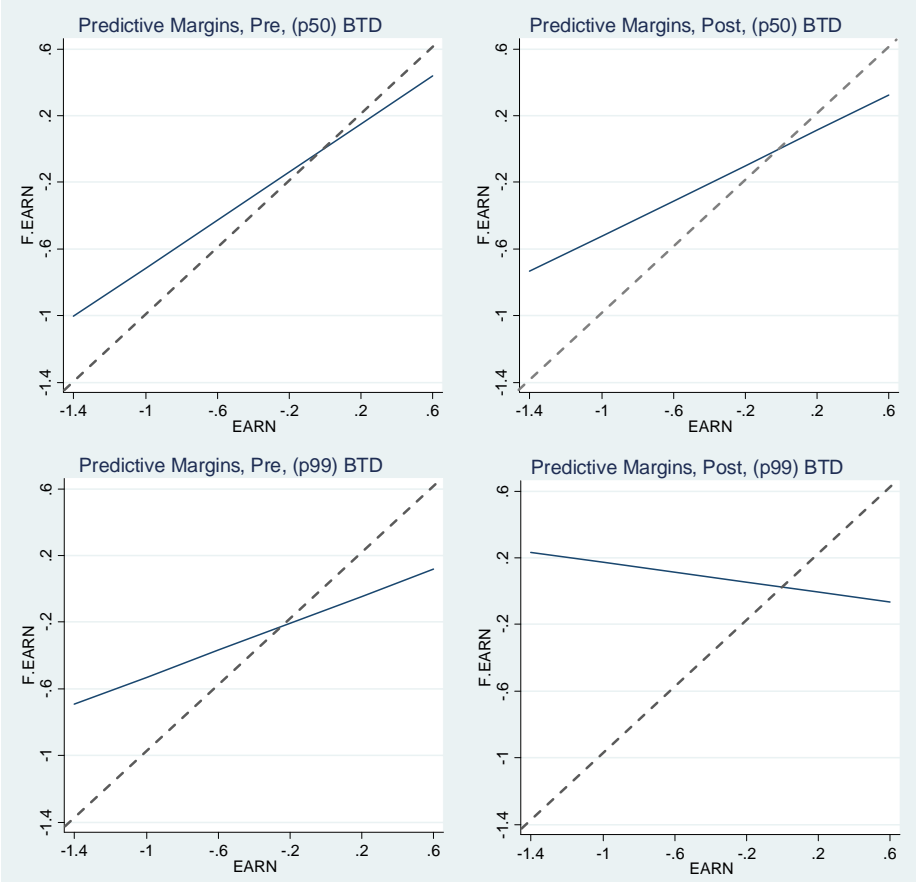

Panel b: Financial accounting earnings
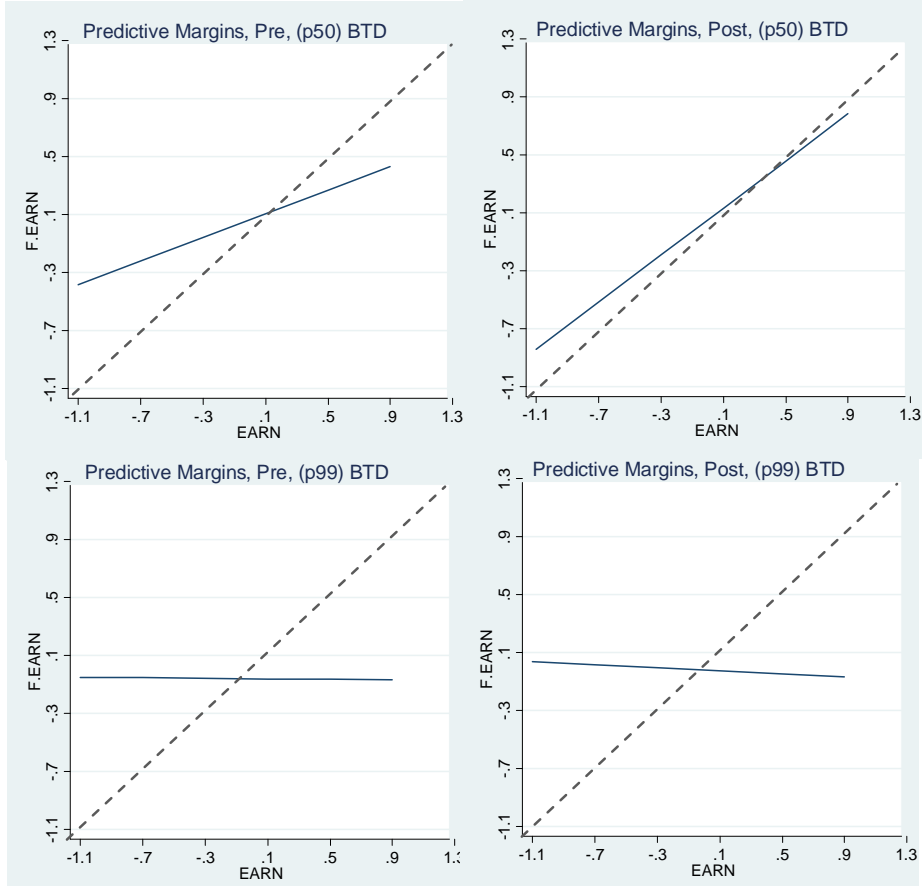

Note: This figure shows graphical results (marginsplots) for the margins analysis of the interaction term $\mathrm{EARN}_{\mathrm{i}, \mathrm{t}} * \mathrm{BTD}_{\mathrm{i}, \mathrm{t}}$ for the $50^{\text {th }}$ and $99^{\text {th }}$ percentile of BTD, separated for the pre- and post-reform period. Panel a contains results for taxable income, panel $\mathrm{b}$ for financial accounting earnings. The dashed grey $45^{\circ}$-line serves as a reference indicating perfect persistence. 